\title{
Macroeconomic implications of early retirement in the public sector: The case of Brazil
}

\author{
Gerhard Glomm $^{\mathrm{a}}$, Juergen Jung ${ }^{\mathrm{b}, *}$, Chung Tran ${ }^{\mathrm{c}}$ \\ a Department of Economics, Indiana University, Bloomington, IN, USA \\ ${ }^{\mathrm{b}}$ Department of Economics, Towson University, MD, USA \\ ' School of Economics, University of New South Wales, Sydney, Australia
}

\section{A R T I C L E I N F O}

\section{Article history:}

Received 29 September 2006

Accepted 29 August 2008

Available online 11 October 2008

\section{JEL classification:}

E21

E62

H55

$\mathrm{J} 26$

J45

\section{Keywords:}

Early retirement

Pension reform

Public sector retirement

Capital accumulation

\begin{abstract}
A B S T R A C T
In Brazil generous public sector pensions have induced civil servants to retire on average at age 55. In this paper we assess the efficiency gains from eliminating such policy induced early retirement in a two-sector overlapping generations economy. We find the adverse effects of that policy are significant. Specifically, the generosity of public sector pensions which induces civil servants to retire 5 years prematurely (at age 55 rather than at age 60) is often associated with decreases in steady state output (GDP) of almost $3 \%$ and welfare losses in the private sector of more than $3 \%$ of consumption.
\end{abstract}

(c) 2008 Elsevier B.V. All rights reserved.

\section{Introduction}

'Early' retirement has become common in the industrialized economies. Blöndal and Scarpetta (1998) report that the effective retirement age in the European Union for men has dropped from about 66 in 1960 to about 61 in 1995, even though life expectancy has increased by roughly 7 years in this period. The retirement age for women has experienced a similar drop. Explanations for the drastic increase in early retirement can be found in Gruber and Wise $(1998,1999)$, Blöndal and Scarpetta (1998), Visco (2000), Herbertsson (2001), Blundell et al. (2002), Herbertsson and Orszag (2003), Conde-Ruiz et al. (2005) and Wise (2005). The literature has established a credible empirical link between the design of pension systems and early retirement decisions. ${ }^{1}$ The costs of early retirement have been estimated to be $7.1 \%$ of GDP in 2000 and up to $9.1 \%$ of GDP in 2010 for the OECD average (compare Herbertsson and Orszag, 2003).

The literature on early retirement for the most part has focused on the industrialized world and ignored developing countries. While this emphasis is justified to some degree, generous pension schemes and early retirement issues are not

\footnotetext{
* Corresponding author. Tel.: +14107043551.

E-mail address: jjung@towson.edu (J. Jung).

${ }^{1}$ Michel and Pestieau (1999), Ahituv and Zeira (2000), Cremer and Pestieau (2003), and Fehr et al. (2003) among others, use overlapping generations models to study how social security policies influence retirement decisions. Rust and Phelan (1997) and Jimenez-Martin and Sanchez (2003) estimate lifecycle models with social security programs to assess the impact of these programs on retirement behavior. Kopecky (2005) argues that early retirement among males in the US can be explained by an increase in the real wage and a decrease in the price of leisure goods.
} 


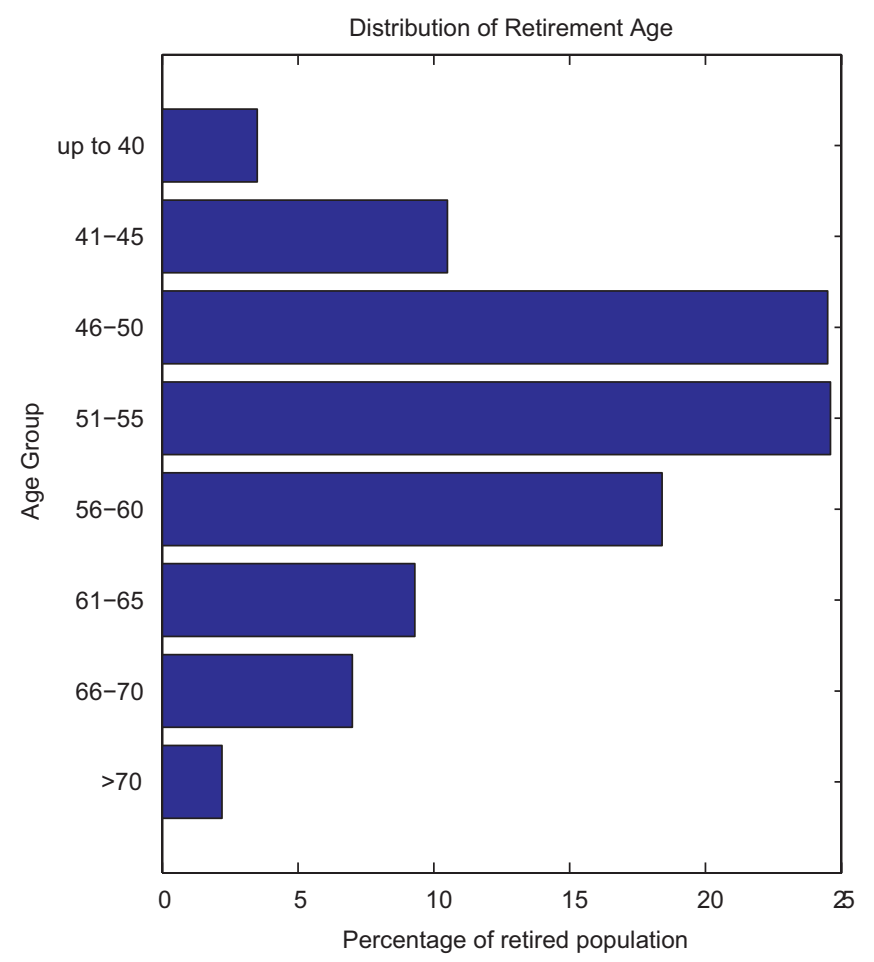

Fig. 1. Distribution of early retirement per age group in the public sector. Source: Ministry of the Budget and Administration, 2002 .

wholly absent in developing countries. In Brazil for example, the public sector pensions rank among the most generous in the world. Public sector pensioners account for about $5 \%$ of all pensioners, yet receive about $50 \%$ of the value of all pension payments. The average contribution rate to public sector pensions is $11 \%$ and much lower than the $27 \%$ contribution rate in the urban private sector.

In Brazil, the constitutionally guaranteed provision of 'integrality' ensures that public sector pensions match the income in the year of retirement of the civil servant. This tends to be the maximum income in the career of a civil servant since pay grades are a function of seniority. ${ }^{2}$ The provision of 'parity' ensures that pension payments are indexed to wages of current civil servants. After retiring from the civil service, workers are allowed to accept jobs in the private sector and receive public sector pensions simultaneously. As a consequence, civil servants retired on average at the age of 54 in 2002 (it was 49 in 1988). Fig. 1 illustrates the retirement age distribution of civil servants of the federal government. ${ }^{3}$ In addition, there have been serious fiscal consequences of generous public pension schemes for civil servants. According to Souza et al. (2004) the deficit of the public sector pension system amounts to $3.5 \%$ of private sector output.

There is a relatively small literature studying the macroeconomic effects of pension reform in developing countries generally or in Brazil specifically. Ferreira (2004) studies social security reform in Brazil in the context of a small open economy. He finds large welfare gains from social security reform. Ferreira (2005) studies the redistributional effect of social security reform along the transition in Brazil. Glomm et al. (2006) study the macroeconomic effects of generous public sector pensions, concentrating on opportunity costs of foregone public education expenditure and infrastructure investment. These studies abstract from early retirement effects.

In this paper we investigate the effects of generous pensions for civil servants. We use an overlapping generations model where a period is 5 years and where individuals become economically active at age 20 and die for sure at age 90 . The government hires civil servants and invests in a public capital which are combined to produce a productive public good. Retirement among civil servants may occur endogenously depending on the design of the pension system. Upon early retirement civil servants are free to pursue employment in the private sector. All government expenditures are financed by taxes on labor, consumption and capital income. We calibrate the model to data from Brazil. We calculate steady state equilibria as well as transition paths between pre- and post- reform steady states.

We find that the efficiency gain from eliminating such policy induced early retirement in the public sector is substantial. Specifically, the policy reform, which decreases the generosity of public sector pensions, and simultaneously increases the minimum retirement age of civil servants from age 55 to 60, increases steady state private sector output by about 3\% when

\footnotetext{
${ }^{2}$ This level of generosity was even surpassed in the military and police force, where the first pension payment matched the highest salary one pay grade higher. Phantom promotions just before retirement may contribute even more to the generosity of public sector pensions.

${ }^{3}$ In 1998, a minimum retirement age for civil servants was established at age 53 for men and age 48 for women.
} 
labor tax rates adjust to clear the government budget. Apart from a grandfathering effect, transitions indicate a smooth monotone progression between steady state output levels. Welfare calculations indicate that private sector workers gain up to $3 \%$ of their average consumption while civil servants lose up to $10 \%$ of their average consumption from this reform. In addition, we find that effects of similar magnitude are obtained when the government uses alternative tax-financing instruments such as a capital income tax and a consumption tax to clear the government budget. We also find that the quantitative effects are fairly robust to changes in the parameters.

The adverse effects of generous public pensions to civil servants have been neglected in the literature because of the assumption that this public pension scheme is relatively small and affects only the public sector workers, who represent only a small fraction of the labor force. The key contribution of this paper is to show that reforming the pension system of a small minority within the group of retirees can substantially change the productivity of an economy when accounting for all general equilibrium effects. We identify three general equilibrium channels that magnify the adverse effects of generous public sector pensions. First, the generosity of public sector pensions causes early retirement in the public sector, which reduces human capital available to the production of public goods. Second, the generosity of public sector pensions results in adverse effects on savings. Third, the generous public pension scheme is costly and has to be financed by taxes, which in turn influence capital accumulation, labor supply and income.

The paper is organized as follows. The next section describes the model. In Section 2 we calibrate the model to Brazil and in Section 3 we conduct policy experiments. We conduct extensive sensitivity analysis for these policy reform experiments in Section 4. Section 5 concludes. The appendix contains the algorithm used to compute the equilibrium.

\section{The model}

\subsection{Heterogeneity}

There is a large number of individuals who live for $J$ periods in an overlapping generations economy. Each period accounts for 70/J years, with working life beginning at age 20 and life ending for sure at age 90. Workers are born with an innate ability that determines their income type. Workers cannot change their income type. In addition, workers can either work in the public sector (civil servants, etc.) or in the private sector. We denote the income type as variable income and the working sector as sector $\in$ \{private,government\}. The agent is then characterized by her age, income type, and working sector. We summarize the income type and working sector in state vector $\theta=\{$ income, sector $\}$. Here and in the rest of the paper the subscripts $p$ and $g$ denote private sector workers and public sector workers, where $g$ stands for government workers. When we need to distinguish between the sectors we fix the sector variable to one of the sectors and use the following state vector notation $\theta_{p}=\{$ income, sector $=$ private $\}$ and $\theta_{g}=\{$ income, sector $=$ government $\}$. The variable $\mu_{j}(\theta)$ denotes the mass of age $j$ agents with characteristic $\theta$. We normalize the population to equal one so that aggregate variables correspond to per capita values. It then has to hold that $\sum_{j=1}^{J} \sum_{\theta} \mu_{j, t}(\theta)=1$.

\subsection{Demographics}

Agents have a random life time. At each age, agents face a mortality shock with a given survival probability $\pi_{j}$. Population grows exogenously at net rate $n$. We assume stable demographic patterns so that, similar to Huggett (1996), age $j$ agents make up a constant fraction $\mu_{j, t}$ of the entire population at any point in time $t$. The relative size of each age cohort $\mu_{j, t}=\sum_{\theta} \mu_{j, t}(\theta)$ is recursively defined as

$$
\mu_{j, t}=\frac{\pi_{j}}{(1+n)} \mu_{j-1, t}
$$

Similarly, the cohort size of agents dying each period (conditional upon survival up to the previous period) can be defined recursively as

$$
v_{j, t}=\frac{1-\pi_{j}}{(1+n)} \mu_{j-1, t}
$$

\subsection{Human capital}

Agents are endowed with one unit of time each period and they provide $\left(1-l_{j, t}\right)$ units of time to the labor market with a given efficiency $e_{j}(\theta)$. We later calibrate this efficiency profile to data which exhibits the typical hump-shaped profile as shown in Fig. 2. Effective labor (or human capital) at each age is given by $h_{j, t}(\theta)=\left(1-l_{j, t}\right) e_{j}(\theta)$.

\subsection{Preferences and technology}

Within each period of their lives agents value a single consumption good and leisure. The per period utility function is

$$
u\left(c_{j, t}(\theta), l_{j, t}(\theta)\right)=\frac{\left(\left(c_{j, t}(\theta)\right)^{\gamma}\left(l_{j, t}(\theta)\right)^{1-\gamma}\right)^{1-\sigma}}{1-\sigma},
$$

where $c$ and $l$ is consumption and leisure, respectively, $0<\gamma \leqslant 1$, and $\sigma>0$. 
The privately supplied good is produced from three inputs, a public good $G_{t}$, the private physical capital stock $K_{t}$, and effective labor (human capital) in the private sector $H_{p, t}$ according to the production function

$$
Y_{t}=A G_{t}^{\alpha_{1}} K_{t}^{\alpha_{2}}\left(H_{p, t}\right)^{\alpha_{3}}
$$

where $\alpha_{i} \in(0,1)$ for $i=1,2,3, \alpha_{2}+\alpha_{3}=1$ and $A>0$. Private physical capital depreciates at rate $\delta_{p}$ each period. The public good in the production function can be thought of as the stock of public infrastructure such as roads. This public good is made available to all firms at a zero price. Specifications of the technology similar to this one have been used by Barro (1990), Turnovsky (1999) and others. Total factor productivity grows exogenously at rate $g$.

The government uses effective labor (human capital) of civil servants $H_{g, t}$ and public capital $K_{g, t}$ to produce infrastructure capital according to

$$
G_{t}=Z\left[\left(K_{g, t}\right)^{\eta}+\chi\left(\omega_{h} H_{g, t}\right)^{\eta}\right]^{1 / \eta},
$$

where $Z, \chi>0$ and $\eta \leqslant 1$. The fraction of civil servants contributing to the production of the public good is denoted $\omega_{h} \in(0,1)$. The remaining civil servants produce government consumption that is not explicitly modelled. This set-up allows us to not only study the costs of public sector compensation including pension benefits but also the benefits of public sector employment.

Public capital evolves according to

$$
K_{g, t+1}=\frac{1}{(1+n)(1+g)}\left(\left(1-\delta_{g}\right) K_{g, t}+I_{g, t}\right),
$$

where we detrend capital with the exogenous population growth rate and the exogenous technological growth rate. Public capital depreciates at rate $\delta_{g}$ in each period.

\subsection{Labor markets and pension legislation}

At the beginning of their life, workers are assigned employment in either the public or private sector. We assume that for all cohorts in all time periods public sector wages exceed those in the private sector in order to mimic the more generous public sector compensation scheme. ${ }^{4}$ Hence all workers prefer public sector jobs to jobs in the private sector. We maintain the assumption that all workers of a given age and type are equally productive regardless of whether they work in the public or private sector.

Labor market legislation allows workers to stay in their initial employment until age $J_{w}$ after which workers have to retire from their initial employment. We think of this as the standard retirement age, i.e. age 65 . There is also an early retirement option. Workers have to work at least until period $J_{e}$, so that the earliest possible retirement period is $J_{e}+1$. Workers can choose their number of working periods $J_{1, t}(\theta)$ in the first job. It follows that $J_{e} \leqslant J_{1, t}(\theta) \leqslant J_{w}$.

Retirees from both the private and public sector can start working again in a second job in the private sector with lower labor productivity. The latter is the result of a skill mismatch. We use factor $0<\varphi<1$ to scale the efficiency profiles downwards. Agents are allowed to work in the second job as long as they want while receiving public pensions. ${ }^{5}$ To simplify our calculations, we force all agents into retirement in their last period of life $J$.

\subsection{Government}

\subsubsection{Government expenditures}

The government uses public capital and hires labor to produce public goods. The fraction of civil servants is fixed exogenously at $N^{g}$. The total wage bill of currently employed civil servants is

$$
\text { Wage }_{t}^{g}=\sum_{\theta_{g}} \sum_{j=1}^{J_{1, t}\left(\theta_{g}\right)} w_{g, t} h_{j, t}\left(\theta_{g}\right) \mu_{j, t}\left(\theta_{g}\right) .
$$

The wages of civil servants are set by the government using a markup $\xi>1$ over private sector wages so that $w_{g, t}=\xi \times w_{p, t}$. Private sector wages are determined by the market.

\footnotetext{
${ }^{4}$ Households in Latin American countries seem to prefer to work in the public sector according to recent evidence. Not only are pension schemes more generous, but also the active wages are higher (see Gregory and Borland, 1999; Panizza, 2001; Panizza and Qiang, 2005). Since we do not model the more secure career path in the public sector (low risk of job loss) vs. the private sector (high risk of job loss) we think that job security should be reflected in higher wages in the public sector.

${ }^{5}$ It is not uncommon in Brazil for public sector early retirees to take a job in the private sector. The possibility of receiving pension payments while working elsewhere constitutes a strong incentive for early retirement. According to Bonturi (2002) public sector early retirees were even able to draw pension payments while working in a different public sector position.
} 
The government runs two separate pension programs, one for public sector workers and one for private sector workers. All workers of both sectors are required to participate in the pension program and consequently have to pay a social security tax $\tau_{\mathrm{SS}, t}^{p}$ and $\tau_{\mathrm{SS}, t}^{g}$. When workers retire they stop paying labor taxes and social security taxes and are eligible to draw pension benefits. We summarize the payout formula to private sector retirees as

$$
\operatorname{Pen}_{j, t}\left(\theta_{p}\right)=\Psi_{j}^{p}\left(J_{1, t}\left(\theta_{p}\right)\right) \times\left(\frac{\sum_{i=J_{1, t}\left(\theta_{p}\right)-J_{p}}^{J_{1, t}\left(\theta_{p}\right)} w_{p, t-J_{1, t}\left(\theta_{p}\right)+i} \times h_{i, t-J_{1, t}\left(\theta_{p}\right)+i}\left(\theta_{p}\right)}{J_{p}}\right),
$$

and the payout formula to public sector retirees as

$$
\operatorname{Pen}_{j, t}\left(\theta_{g}\right)=\Psi_{j}^{g}\left(J_{1, t}\left(\theta_{g}\right)\right) \times\left(\frac{\sum_{i=J_{1, t}\left(\theta_{g}\right)-J_{g}}^{J_{1}\left(\theta_{g}\right)} w_{g, t-J_{1, t}\left(\theta_{g}\right)+i} \times h_{i, t-J_{1, t}\left(\theta_{g}\right)+i}\left(\theta_{g}\right)}{J_{g}}\right) .
$$

Note that the payout formula for private sector workers is a function of the workers average earnings income over the last $J_{p}$ periods of her active work life. The respective period for public sector workers is denoted $J_{g}$. The government policy variables $J_{p}$ and $J_{g}$ are set exogenously. The terms in brackets on the right hand side of Eqs. (3) and (4) represent average earnings of agent type $\theta_{p}$ and $\theta_{g}$ over the most recent $J_{p}$, respectively, $J_{g}$ periods. Therefore, the size of the pension program will be endogenous.

In addition, the pension scheme for public sector workers differs from the scheme for private sector workers in contribution rates and benefit payments. The government sets the pension replacement rates for the private sector $\Psi_{j}^{p}\left(J_{1}\left(\theta_{p}\right)\right)$ as a function of the retirement age $J_{1, t}\left(\theta_{p}\right)$ and the current age $j$ of a type $\theta_{p}$ private sector worker. An agent who retires later will enjoy a higher pension replacement rate, i.e. $\Psi_{j}^{p}$ (65 years) $>\Psi_{j}^{p}$ (60 years).

The pension replacement rates for public sector workers $\Psi_{j}^{g}\left(J_{1, t}\left(\theta_{g}\right)\right)$ will be set to capture the principle of 'integrality' in the public sector. That is, a public sector worker does not experience a drop in income after retirement, because the government fully replaces the most recent active wage income. In this sense $J_{g}=1$, as pensions are calculated according to last periods' wage income. Note also that transfer payments to public sector workers are more generous than replacement rates for private sector workers. The total pension payments to private sector retirees and to public sector retirees are given by

$$
\begin{aligned}
\operatorname{Pen}_{t}^{p} & =\overbrace{\sum_{\theta_{p}} \sum_{j=J_{1, t}\left(\theta_{p}\right)+1}^{J} \operatorname{Pen}_{j, t}\left(\theta_{p}\right) \mu_{j, t}\left(\theta_{p}\right)}^{\text {total pensions private sector workers }} \text { and } \\
\operatorname{Pen}_{t}^{g} & =\overbrace{\sum_{\theta_{g}} \sum_{j=J_{1, t}\left(\theta_{g}\right)+1}^{J} \operatorname{Pen}_{j, t}\left(\theta_{g}\right) \mu_{j, t}\left(\theta_{g}\right)}^{\text {total pensions public sector workers }}
\end{aligned}
$$

The government finances investment in public capital $I_{g, t}=\Delta_{g, t} Y_{t}$, where $\Delta_{g, t}$ is the fraction of private sector output allocated to public investments. The remainder of government expenditure $C_{g, t}$ is government consumption. We let $C_{g, t}=$ $\Delta_{C_{g, t}} Y_{t}$. Government consumption is unproductive.

\subsubsection{Government income}

The government collects labor income taxes in the private and public sector at the rates $\tau_{L, t}^{p}$ and $\tau_{L, t}^{g}$ as well as social security taxes $\tau_{\mathrm{SS}, t}^{p}$ and $\tau_{\mathrm{SS}, t}^{g}$. Accidental bequests are taxed at $\tau_{\mathrm{Beq}, t}$. The government also taxes consumption at rate $\tau_{C, t}$ and capital income net of depreciation $\left(q_{t}-\delta\right) K_{t}$ at rate $\tau_{K, t}$, where $q_{t}$ is the capital rental rate. The total tax revenue is given by

$$
\begin{aligned}
\operatorname{Tax}_{t}= & \overbrace{\left(\tau_{L, t}^{p}+\tau_{S S, t}^{p}\right) \sum_{\theta_{p}}^{J_{1, t}\left(\theta_{p}\right)} w_{j=1} w_{p, t} h_{j, t}\left(\theta_{p}\right) \mu_{j, t}\left(\theta_{p}\right)}^{\text {labor and soc. sec. income tax from the private sector }}+\overbrace{\left(\tau_{L, t}^{g}+\tau_{S S, t}^{g}\right) \sum_{\theta_{g}} \sum_{j=1}^{J_{1, t}\left(\theta_{g}\right)} w_{g, t} h_{j, t}\left(\theta_{g}\right) \mu_{j, t}\left(\theta_{g}\right)}^{\text {labor and soc. sec. income tax from the public sector }} \\
& +\overbrace{\tau_{\text {Beq, }} \sum_{\theta} \sum_{j=1}^{J} a_{j, t}(\theta) v_{j, t}(\theta)}^{\text {tax on bequests }}+\overbrace{\tau_{K, t}\left(q_{t}-\delta\right) K_{t}}^{\text {capital tax }}+\overbrace{\tau_{C, t} \sum_{\theta} \sum_{j=1}^{J} c_{j, t}(\theta) \mu_{j, t}(\theta)}^{\text {consumption tax }} .
\end{aligned}
$$


In addition, the government can borrow a fixed fraction $\Delta_{B, t}$ of its GDP each period. These bonds are denoted $B_{t}=$ $\Delta_{B, t-1} Y_{t-1}$, where $\Delta_{B, t}$ is set exogenously. Newly issued bonds have to be detrended with the exogenous technological growth rate $g$ and the exogenous population growth rate $n .^{6}$

The government budget constraint can be expresses as

$$
R_{t} B_{t}+C_{g, t}+I_{g, t}+\text { Wage }_{t}^{g}+\operatorname{Pen}_{t}^{p}+\operatorname{Pen}_{t}^{g}=\operatorname{Tax}_{t}+(1+g)(1+n) B_{t+1} .
$$

\subsection{Household problem}

In general, households in the private and the government sector have similar maximization problems. Households decide their consumption and leisure $\left\{c_{j, t}(\theta), l_{j, t}(\theta)\right\}_{j=1}^{J(\theta)}$ as well as their retirement age $J_{1, t}(\theta)$ as a function of their income type and their sector of employment as summarized in state vector $\theta$. The household problem can be recursively formulated as

$$
V_{t}\left(a_{j, t}(\theta), \theta\right)=\max _{\left.\bigcup_{1, t}(\theta), a_{j, t}(\theta), c_{j, t}(\theta), l_{j, t}(\theta)\right\}}\left\{\frac{\left(\left(c_{j, t}(\theta)\right)^{\gamma}\left(l_{j, t}(\theta)\right)^{1-\gamma}\right)^{1-\sigma}}{1-\sigma}+\beta \pi_{j} V_{t+1}\left(a_{j+1, t+1}(\theta), \theta\right)\right\}
$$

s.t.

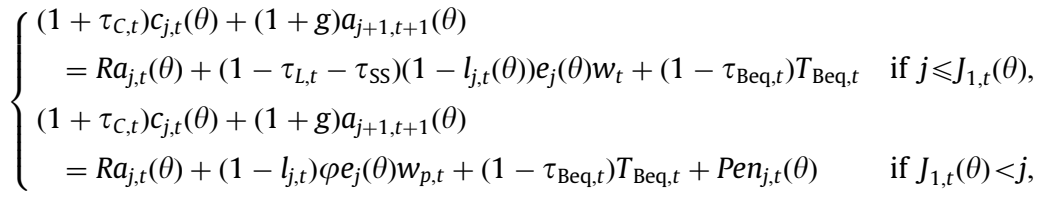

$$
\begin{aligned}
& 0 \leqslant a_{j, t}(\theta), \\
& 0<l_{j, t}(\theta) \leqslant 1,
\end{aligned}
$$

where $j=\{1,2, \ldots, J\}, w_{t}=\left\{w_{p, t}\right.$ or $\left.w_{g, t}\right\}$ is the individual wage rate which is sector specific, $T_{\text {Beq }}$ are transfers of accidental bequests that are taxed at rate $\tau_{\mathrm{Beq}, t}$ and $\varphi$ is a scaling factor that reduces the efficiency profile of retirees who continue to work in the informal sector with lower efficiency.

\subsection{Firm problem}

The firm problem is standard. Given the level of public capital and given factor prices, firms hire physical capital and human capital to maximize profits. Thus a firm's problem is

$$
\max _{\left(H_{p, t}, K_{t}\right)} F\left(G_{t}, K_{t}, H_{p, t}\right)-w_{p, t} H_{p, t}-q_{t} K_{t} \text { given }\left(w_{p, t}, q_{t}, G_{t}\right) \text {. }
$$

\subsection{Definition of equilibrium}

Given the government policy $\left\{\tau_{L, t}^{p}, \tau_{L, t}^{g}, \tau_{S S}^{p}, \tau_{S S}^{g}, \tau_{B, t}, \tau_{K, t}, \Delta_{B, t}, \Delta_{G, t}, \Delta_{C_{G}, t}, \xi_{t}, \Psi_{t}^{p}, \Psi_{t}^{g}\right\}_{t=0}^{\infty}$, a competitive equilibrium with endogenous retirement is a collection of sequences of decisions of privately and publicly employed households $\left\{l_{j, t}(\theta), c_{j, t}(\theta), a_{j+1, t+1}(\theta)\right\}_{t=0}^{\infty}$ and sequences of retirement decisions $\left.J_{1, t}(\theta)\right\}_{t=0}^{\infty}$ where $j=\{1, \ldots, J\}$, and sequences of aggregate stocks of private physical capital and private human capital $\left\{K_{t}, H_{p, t}\right\}_{t=0}^{\infty}$, sequences of aggregate stocks of public physical capital and public human capital $\left\{K_{G, t}, H_{g, t}\right\}_{t=0}^{\infty}$, and sequences of factor prices $\left\{w_{p, t}, w_{g, t}, q_{t}\right\}_{t=0}^{\infty}$ such that

(i) the sequence $\left\{l_{j, t}(\theta), c_{j, t}(\theta), a_{j+1, t+1}(\theta)\right\}_{t=0}^{\infty}$ solves the household maximization problem (6),

(ii) factor prices are determined by

$$
\begin{aligned}
& q_{t}=\alpha \frac{Y_{t}}{K_{t}}, \\
& w_{p, t}=(1-\alpha) \frac{Y_{t}}{H_{t}^{p}}, \\
& w_{g, t}=\xi w_{p, t}, \\
& R_{t}=1+\left(1-\tau_{K, t}\right)\left(q_{t}-\delta_{p}\right)=1+\left(1-\tau_{K, t}\right) r_{t},
\end{aligned}
$$

\footnotetext{
${ }^{6}$ Fuster et al. (2005) use similar exogenous growth rates.
} 


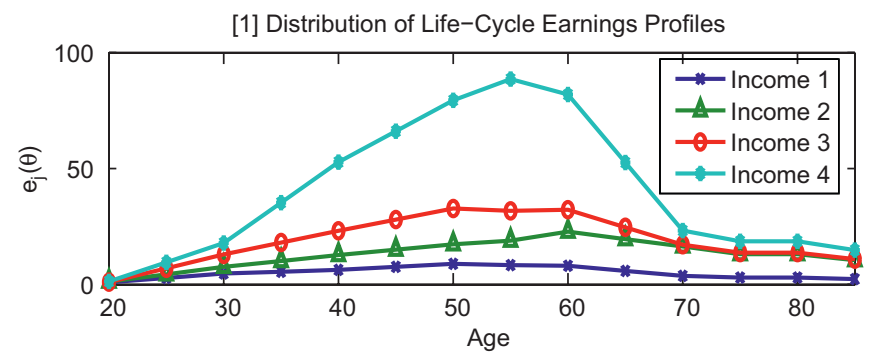

[2] Private Sector: Replacement Rates

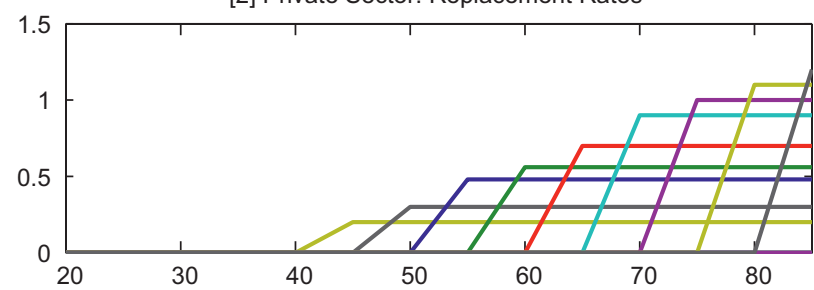

[3] Public Sector: Replacement Rates

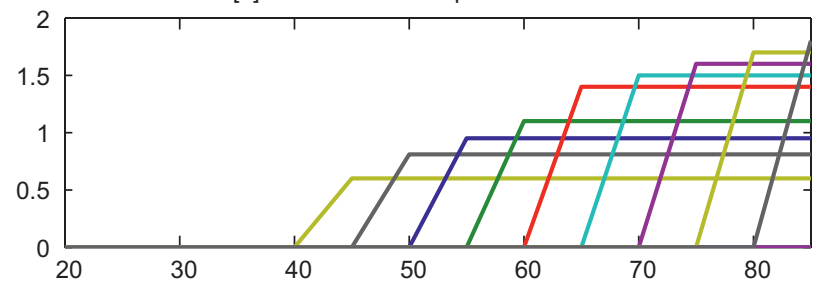

Fig. 2. Efficiency-age profiles of private and public sector workers by ability type and pension replacement rates as a function of the year of retirement.

(iii) aggregate variables are given by

$$
\begin{aligned}
& A_{t}=\sum_{\theta} \sum_{j=1}^{J} a_{j, t}(\theta) \mu_{j, t}(\theta)+\overbrace{\sum_{\theta} \sum_{j=1}^{J} a_{j, t}(\theta) v_{j, t}(\theta)}^{\text {accidental bequests }} \\
& K_{t}=A_{t}-B_{t}, \\
& H_{t}^{p}=\sum_{\theta_{p}} \sum_{j=1}^{J} h_{j, t}\left(\theta_{p}\right) \mu_{j, t}\left(\theta_{p}\right)+\overbrace{\sum_{\theta_{g}} \sum_{j=J_{1, t}\left(\theta_{g}\right)+1}^{J} h_{j, t}\left(\theta_{g}\right) \mu_{j, t}\left(\theta_{g}\right),}^{\text {public sector retirees working in (informal) priv }} \\
& H_{t}^{g}=\sum_{\theta_{g}} \sum_{j=1}^{J_{1, t}\left(\theta_{g}\right)} h_{j, t}\left(\theta_{g}\right) \mu_{j, t}\left(\theta_{g}\right), \\
& S_{t}=\sum_{\theta} \sum_{j=1}^{J} a_{j+1, t+1}(\theta) \mu_{j, t}(\theta), \\
& C_{t}=\sum_{\theta} \sum_{j=1}^{J} c_{j, t}(\theta) \mu_{j, t}(\theta),
\end{aligned}
$$

(iv) commodity markets clear $^{7}$

$$
C_{t}+(1+g) S_{t}+I_{g, t}+C_{g, t}=Y_{t}+\left(1-\delta_{p}\right) K_{t}+B_{t},{ }^{8}
$$

\footnotetext{
${ }^{7}$ Since the public good $G$ is an input into private sector production of $Y$, the public sector wage bill is already contained in the measure of $Y$. For simplicity we do not take net exports into account when expressing policy parameters as percentage of GDP. Since according to WorldBank (2006) net exports in Brazil are only approximately $1.5 \%$ of GDP we think this is an acceptable compromise.

${ }^{8}$ The aggregate savings $S_{t}$ already incorporates the exogenous population growth rates via the population weight $\mu$. We therefore only have to detrend with the exogenous technological growth rate $g$.
} 
(v) accidental bequests are returned in lump sum transfers to surviving agents

$$
T_{B, t}=\frac{\sum_{\theta_{p}} \sum_{j=1}^{J} a_{j, t}\left(\theta_{p}\right) v_{j, t}\left(\theta_{p}\right)+\sum_{\theta_{g}} \sum_{j=1}^{J} a_{j, t}\left(\theta_{g}\right) v_{j, t}\left(\theta_{g}\right)}{\sum_{\theta} \sum_{j=1}^{J} \mu_{j, t}(\theta)},
$$

(vi) and the government budget constraint (5) holds.

\section{Calibration}

We solve the model for steady states using a numerical algorithm similar to Auerbach and Kotlikoff (1987). This algorithm solves a complicated set of non-linear equations using an iterative technique commonly referred to as the Gauss-Seidl method. The algorithm starts with a guess of various endogenous variables and treats them as exogenous. Then the algorithm solves for a new set of endogenous variables. If the new set of endogenous variables equals the original guesses, a solution to the system has been found and the algorithm stops. Otherwise, we take linear combinations of the guessed variables and the new solutions for the variables and start all over. Once the algorithm converges to a steady state, we compare the model's outcome to moments in the data for Brazil. We then conduct a policy experiment (reduction of public sector pension generosity together with an increase in the mandatory retirement age of public sector workers) and calculate the new steady state. We use a similar algorithm to solve for transitions between these two equilibrium allocations. We describe the algorithm more formally in the appendix. ${ }^{9}$

\subsection{Heterogeneity}

We calibrate a $J=14$ period OLG model to Brazilian data. Each model period corresponds to 5 years. Agents become economically active at age 20 and die for sure at age 90. We differentiate among four income types and two sector types, $\theta=\{$ income $=\{1,2,3,4\}$, sector $=\{$ private, public $\}$. We calibrate the relative size of the four income groups according to data from Ferreira et al. (2003) on educational attainment in Table 1. In addition, Panizza (2000) reports that roughly 60\% of all public sector workers in Brazil have a high-school or university degree. We assume an even split between workers with 9-12 years of education and workers with $12+$ years of education. We now know the absolute number of workers per education group as well as the decomposition of workers per education group in the public sector. We can therefore calculate the decomposition of workers per education group in the private sector as a residual. We report these numbers in the last row of Table 1 . The fraction of public sector workers is fixed exogenously at $N^{g}=7 \%$ (Social Security Ministry of Brazil, 2002).

\subsection{Demographics}

The survival probabilities are calculated from Brazilian life tables for the year $2001 .^{10}$ The population growth rate is equal to $n=7.73 \%$ per period which corresponds to an annual growth rate of $1.8 \%{ }^{11}$ This results in $14.16 \%$ of the population being older than 65. Carvalho and Wong (2004) report roughly $15 \%$ for the year 2000 for that ratio. ${ }^{12}$ We summarize the initial parameter choices for our model in Table 4.

Table 1

Educational attainment of labor force

\begin{tabular}{llllll}
\hline Income group & 1 & 2 & 3 & 4 \\
\hline Education in years of schooling & $0-4$ & $5-8$ & $9-12$ & $12+$ \\
Total population & $41.89 \%$ & $30.10 \%$ & $20.56 \%$ & $7.45 \%$ & $30 \%$ \\
Public (7\% of total pop.) & $10 \%$ & $30 \%$ & $30 \%$ & Ferreira et al. (2003) \\
Private (93\% of total pop.) & $44.67 \%$ & $29.90 \%$ & $19.72 \%$ & Panizza (2000) \\
\hline
\end{tabular}

\footnotetext{
${ }^{9}$ There is no formal proof of uniqueness available for this type of Auerbach-Kotlikoff models (see Kotlikoff et al., 2007). Laitner (1984) provides a proof of uniqueness for a linearized version of the original Auerbach-Kotlikoff model.

Our solution algorithm is locally stable. That is for changes in initial conditions (guesses of initial prices $R$ and $w$ ) the algorithm converges to the same steady state. We have no proof of global convergence. It has been our experience that higher order dynamics in multiperiod OLG models with bonds can lead to multiple steady states. In such cases we were able to rule out Pareto inferior steady states (e.g. steady states that result in negative interest rates). Compare also Colucci (2003) who shows the existence of at least two steady states in a very simple multi period OLG model.

${ }^{10}$ The life tables are available at the following WHO website: http://www3.who.int/whosis/life/life_tables.

11 See the OECD Factbook 2006 - Economic, Environmental and Social Statistics that also contains the annual growth rates for Brazil for the years 1981-2004 at http://titania.sourceoecd.org/vl=3134242/cl=11/nw=1/rpsv/factbook/01-01-01-g02.htm.

12 Note that these shares are computed using a total population that excludes individuals that are younger than 20 years of age. Projections for Brazil indicate that the population aged 65 and older will represent about $16 \%$ of the total population (including $1-19$ year olds) by the year 2050 (e.g. Turra and Queiroz, 2005a).
} 
Table 2

Labor Income by age and level of education, Brazil 1996

\begin{tabular}{|c|c|c|c|c|}
\hline \multirow[t]{2}{*}{ Age group } & \multicolumn{4}{|c|}{ Labor income (in $\mathrm{R} \$$ ) } \\
\hline & $0-4$ & $5-8$ & $9-11$ & $12+$ \\
\hline 10-19 & 418 & 517 & 430 & 554 \\
\hline $20-29$ & 1,975 & 3,184 & 5,205 & 7,463 \\
\hline $30-39$ & 2,636 & 5,301 & 8,296 & 22,044 \\
\hline $40-49$ & 3,735 & 7,237 & 11,553 & 33,183 \\
\hline $50-59$ & 2,107 & 5,954 & 6,183 & 28,526 \\
\hline $60-69$ & 971 & 4285 & 4,077 & 8,103 \\
\hline $70+$ & 258 & 121 & 596 & 1353 \\
\hline
\end{tabular}

Source: The Living Standards Measurement Survey of Brazil (PPV) as reported in Turra and Queiroz (2005b).

\subsection{Human capital}

We use data from the Living Standards Measurement Survey of Brazil (PPV) from 1996 to 1997 as reported in Turra and Queiroz (2005a) to generate efficiency profiles per income group and age, $e_{j}(\theta)$. We summarize the PPV survey data in Table 2. We then generate efficiency profiles per income group (as measured by the educational attainment) using linear interpolation between the data points. Since data are only available up to age group 70+ we extrapolate the data to age 90 . The resulting efficiency profiles are reported in the top panel of Fig. 2.

The actual income profiles per income group are calculated as

$$
w h_{j}(\theta)=w \times e_{j}(\theta) \times\left(1-l_{j}(\theta)\right),
$$

and reported in the bottom panels of Fig. 3 for private and public workers. The public sector income-age profile is higher reflecting the more generous compensation (wages and pensions) in the public sector.

\subsection{Preferences and technology}

Both, the time discount factor $\beta$ and preference parameter $\sigma$ are chosen to match the capital output ratio and the real interest rate. ${ }^{13}$ The discount factor $\beta$ takes a standard value. Estimates for $\sigma$, the inverse of the intertemporal elasticity of substitution, for Brazil range from 1 to 5 (see Issler and Piqueira, 2000; Soriano and Nakane, 2003). In our benchmark model we set $\sigma=2$ and perform sensitivity analysis. The consumption preference parameter $\gamma=0.23$ is chosen to get labor supply to be around 40 hours a week for agents in their prime working age from 25 to 55 and to target (in conjunction with the pension replacement rates) the correct retirement age which is between 50 and 55 for public sector workers and between 60 and 65 for private sector workers. This results in a coefficient of relative risk aversion in consumption of $C R R A=-c u_{c c} / u_{c}=\sigma \gamma+1-\gamma=1.23$, so that the intertemporal elasticity of substitution in consumption is $1 / C R R A=$ 0.813 . Consequently, in our model the resulting capital output ratio is equal to 2.52 and the annual after tax real interest rate is $R=8.2 \%$ which compares well with the 9.6\% short term real interest rate for 2004 reported in Rogoff (2005). The average short term rate for 2005 was $12 \%$. The capital output ratio of Brazil is between 2.6 and 3 (e.g. Gomes et al., 2003 ; Bresser-Pereira, 1990; Souza-Sobrinho, 2004). ${ }^{14}$

Total factor productivity $A$ is normalized to one. Standard estimates of capital's share of GDP are around $\alpha_{2}=0.3$ (see Gollin, 2002). Estimates for Brazil tend to be higher. Ferreira and do Nascimento (2005) use a value of 0.4 for capital's share of GDP in Brazil. We use the same value.

The estimates for $\alpha_{1}$, the productivity parameter of the public good in the final goods production function, for the US cluster around 0 when panel data techniques are used (e.g. Hulten and Schwab, 1991; Holtz-Eakin, 1994) and they cluster around 0.2 when GMM is used to estimate Euler equations (e.g. Lynde and Richmond, 1993; Ai and Cassou, 1995). Calderon and Serven (2003) estimate this parameter to be around 0.15 and 0.20 . For a cross-section of low income countries including Latin American countries Hulten (1996) obtains an estimate for $\alpha_{1}$ of 0.10 . We use this conservative estimate in order to not overstate our results.

The annual capital depreciation rate $\delta_{p}$ for Brazil is $4 \%$ as reported in Feu (2004). Ferreira and do Nascimento (2005) use $\delta_{p}=6.56 \%$. In our benchmark calibration we use $\delta_{p}=5 \%$ and set the depreciation rate for public sector capital $\delta_{g}$ equal to $5 \%$ as well.

\footnotetext{
${ }^{13}$ It is clear that in a general equilibrium model every parameter affects all equilibrium variables. Here we associate parameters with those equilibrium variables that they affect quantitatively the most.

${ }^{14}$ Capital $K$ is a stock variable, whereas output $Y$ is a flow variable over the 5 year period. In order to calculate the capital output ratio we have to adjust for the number of years per period, so that $K /(Y / 5)$ is the capital output ratio that we report.
} 
[1] Average Assets: Private

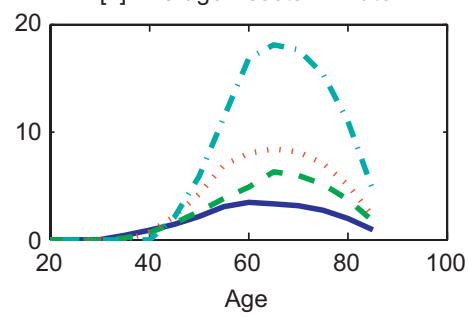

[3] Labor Supply: Private

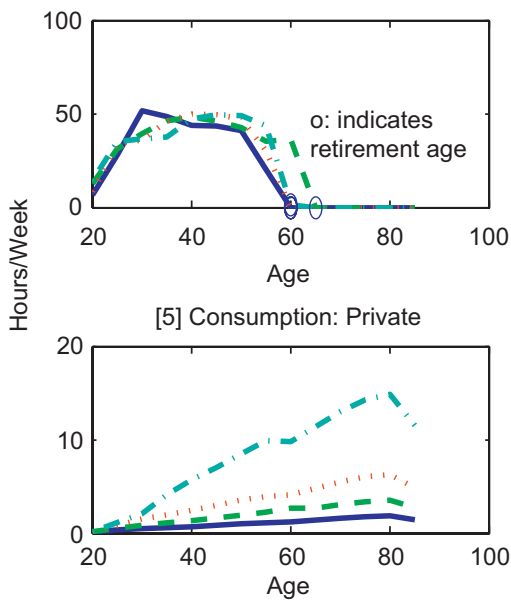

[7] Income Profile: Private

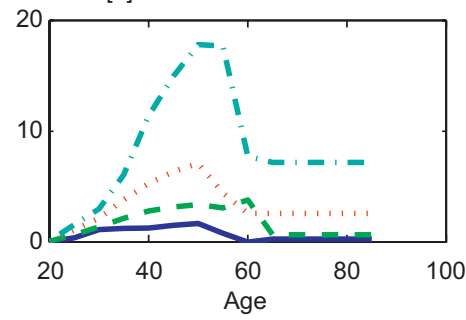

[2] Average Assets: Public

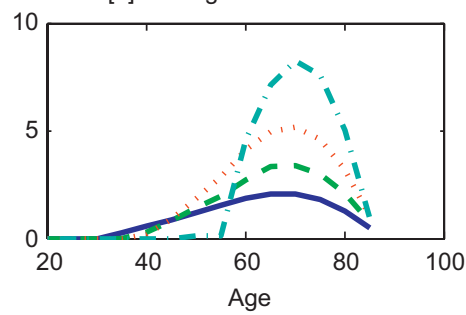

[4] Labor Supply: Public

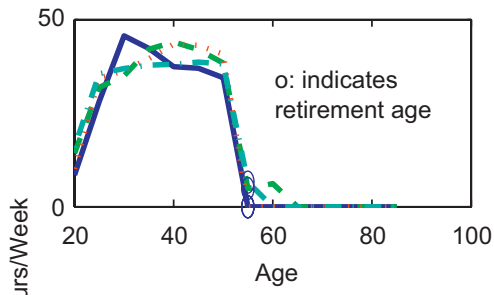

[6] Consumption: Public

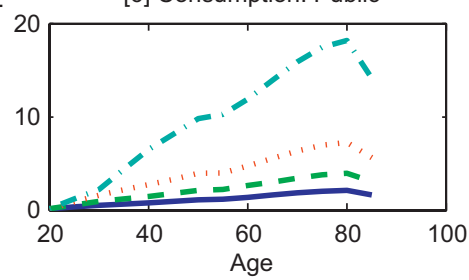

[8] Income Profile: Public

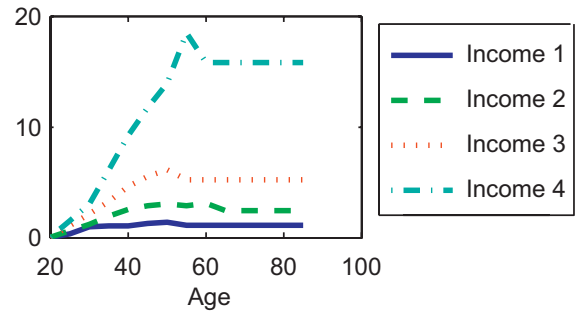

Fig. 3. Benchmark steady state.

The growth rate of GDP is set exogenously to $g=2.65 \%$. This is the average GDP growth rate for the period 1991-2000. ${ }^{15}$

We have little information about the parameters of the production technology of the public good. We view the choice of $Z=0.1, \chi=1, \eta=0.5$ and $\omega_{h}=0.5$ as our benchmark and we perform sensitivity analysis on these parameters. We find that our qualitative and quantitative results are relatively robust to changes in $Z, \eta, \chi$ and $\omega_{h}$.

\subsection{Labor market legislation}

The earliest retirement age possible is 50 , i.e. $J_{e}=7$. We force all agents to retire at age 65 , or $J_{w}=9$. The scaling factor for the efficiency loss of retirees who continue to work is set to $\varphi=0.65$. We do not have data on the productivity losses of working retirees in their new (informal sector) jobs, so we conduct sensitivity analysis. Note that when $\varphi=1$, then the early retirement decision becomes trivial, as all workers will retire at the earliest time possible $\left(J_{e}=6\right.$, or age 50$)$ and then continue to work in the informal sector where they pay almost no taxes. ${ }^{16}$

\footnotetext{
${ }^{15}$ Compare: http://www.brazil.org.uk/economy/gdp.html. Per capita growth rates were much lower. From 1980 to 1990 per capita GDP grew between $-0.56 \%$ and $0.3 \%$ per year. Thereafter the average per capita growth rate of GDP was between $1.06 \%$ and $1.2 \%$ according to the source above and Ferreira and do Nascimento (2005).

${ }^{16}$ The only reason why agents would be willing to work longer, would be to become eligible for higher pension replacement rates when they postpone their retirement. Only very stark differences in replacement rates per postponed year of retirement would then entice them to not immediately retire. With the replacement rates used in our calibration this never happens.
} 
Table 3

Sources of tax revenue from Immervoll et al. (2006)

\begin{tabular}{|c|c|c|c|}
\hline Categories in data & Tax revenue in percent of GDP & Categories in model & Tax revenue in percent of GDP \\
\hline Personal and corporate income tax & 6.2 & Labor tax & 5.2 \\
\hline Social security tax & 6.2 & Capital tax & 7.6 \\
\hline Other payroll taxes & 2.1 & Consumption tax & 15.5 \\
\hline VAT & 11.5 & Social security tax & 6.2 \\
\hline Property tax & 1 & Tax on Bequests & 0.5 \\
\hline Turnover tax & 8 & & \\
\hline Total tax revenue & 35 & & 35 \\
\hline
\end{tabular}

\subsection{Government}

The government policy parameters are summarized in Table 5. We choose a markup rate for public sector wages of $\xi=1.01$. Foguel et al. (2000) report that even not counting the large share of low wage informal employment in the private sector there is still a considerable markup left in public sector wages over formal private sector wages. The chosen markup results in a public sector wage bill of $6 \%$ of GDP. The Social Security Ministry of Brazil (2002) reports a public sector wage bill of $5.1 \%$ of GDP.

The collection of parameters in replacement matrix $\Psi^{p}\left(\theta^{p}\right)$ and $\Psi^{g}\left(\theta^{g}\right)$ can be thought of as gross replacement rates of pension payments. They capture the relatively low replacement rates of private sector pensions and the high replacement rates ensured by integrality and parity in the public sector. ${ }^{17}$ The gross replacement rates for private and public sector workers are a function of the actual retirement period. If an agent retires later in life, the pension replacement rate will be higher. Bonturi (2002) presents average age profiles together with pension benefits over the life of an agent. We mimic those results and present our replacement rates in the bottom panels of Fig. 2 . In addition, we fix the pension of the lowest income groups at a relatively low rate and make it independent from the retirement age. This mimics the fact that for a large proportion of the rural population in Brazil the pension is an anti-poverty measure. These minimum pensions do not exceed the minimum wage.

We set $J_{p}=5$ and $J_{g}=1$, so that pension payments of a private sector worker are based on her average earnings over the last 25 years, whereas pension payments of a public sector worker are based on the wage income earned in the last active period (integrality).

With these replacement rates private sector workers retire at age 65 except for the second lowest income group who retire at age 70 . None of them chose to continue work in the informal sector. Public sector workers retire earlier at age 55 due to the more generous pension payments. The actual retirement age per income group is indicated with circles in the labor supply graphs in Fig. 3. Income groups 2 and 4 continue to work 10 hours on average in the informal private sector.

The size of the pension program is endogenous. The total pension payments to private sector workers in the model are $8 \%$ of private sector output whereas pension payments to civil servants are $5.16 \%$. These numbers are close to the numbers reported in Souza et al. (2004) (6.3\% for private sector workers and 5\% for civil servants). The fraction of public sector retirees among all retirees is $9.9 \%$. Immervoll et al. (2006) report that of all retirees $14 \%$ used to work in the public sector.

According to Immervoll et al. (2006) total tax revenue of 35\% of GDP can be split into the following six parts: $6.3 \%$ is revenue from personal income taxes and corporate income taxes, another $6.3 \%$ is from social security taxes, $2.1 \%$ is from additional payroll taxes, $11.5 \%$ is from VAT taxes, $1.05 \%$ from property taxes, and the remaining $8 \%$ are largely raised from turnover taxes. ${ }^{18}$ Since our model only has five tax categories, i.e. taxes on labor, capital, consumption, bequests, and social security taxes, we need to assign the remaining categories in the data in a meaningful way. Table 3 presents the final tax revenue decomposition that we use in the model. Labor tax revenue is half of the income tax category added to the payroll tax revenue. Capital tax revenue is half of the income tax revenue, half of the property tax revenue and half of the revenue from turnover taxes. Consumption tax revenue is the VAT category and half of the turnover tax. Social security taxes are unaltered. Tax revenue from taxing bequests is half of the revenue from property taxes. In order to match these tax revenue shares we have to pick the following tax rates in our model: $\tau_{L}^{p}=7.6 \%, \tau_{L}^{g}=3.8 \%, \tau_{K}=15 \%, \tau_{C}=23 \%$, and $\tau_{\text {Beq }}=8 \%$.

\footnotetext{
${ }^{17}$ Bonturi (2002) reports that a private sector worker that actively contributed to the pension system will receive roughly $80 \%$ of her highest wage or salary as pension payment. If the worker did not contribute to the system during her worklife she is still entitled to get a minimum pension that is equal to the minimum wage level after reaching retirement age. This is an anti-poverty measure and concerns mostly rural sector workers who are roughly $30 \%$ of private sector retirees. Only half of the private sector labor force contributes to the pension system. Almost all workers in the informal sector, like rural workers and domestic employees, do not contribute. In 1999, there were close to 18 million recipients of social security transfers and roughly one-third of them got the minimum wage level transfer. In our model, we index retirement benefits of private sector workers to the last wage income (the highest one). In order to match the data we need to choose relatively small values for $\Psi^{r}$.

${ }_{18}$ Turnover taxes are similar to sales or VAT taxes but tax intermediate or possibly capital goods (e.g. wholesale sales taxes fall under this category). See Werneck (2006) for details on Brazil's tax reform in 2003.
} 
The actual social security tax rates are $11 \%$ for the public sector and $27.6 \%$ for the private sector (employee $7.65 \%$ and employer 20\%) according to Souza et al. (2004). Since Pinheiro (2004) and Giambiagi and de Mello (2006) report that only $50 \%$ of private sector workers are contributing to the private sector pension plan - informal sector workers do not contribute - we use a payroll social security tax of $11 \%$ for both sectors but allow the labor tax rate in the public sector to be $50 \%$ smaller than the labor tax rate in the private sector.

In the model, this results in pension deficits of $1.5 \%$ of GDP for the private sector pension system and a deficit of $4.4 \%$ of GDP for the public sector pension system. Data suggest that the private pension program produces a deficit between $1.7 \%$ and 2.2\% of GDP (see Pinheiro, 2004; Giambiagi and de Mello, 2006) and the public sector program runs a deficit of 2.6-3.5\% of GDP (see Pinheiro, 2004; Souza et al., 2004).

The pension contribution rates in the private sector are around 80\% according to Souza et al. (2004), whereas the contribution rates in the public sector range from $13.4 \%$ to $36 \%$ according to data from the Ministry of Budget and Administration (1999) and Souza et al. (2004). Contribution rates are defined as tax revenue collected from payroll taxes over total pension payments of the particular pension program. We calibrate contribution rates of $81.8 \%$ for the private sector and $13.15 \%$ for the public sector in our benchmark calibration.

In our model public capital investment is $\Delta_{G}=3 \%$ of private sector output. This is close to a value reported by Calderon and Serven (2003) and the range of public investment reported in Ferreira and do Nascimento (2005). They report that public investment as a proportion of GDP averaged 4\% of GDP between 1960 and 1980. In 2002 and 2003 it was much lower at $2.2 \%$.

Newly issued government debt as a fraction of GDP is $\Delta_{B}=8 \%$, which results in a steady state debt level of $35 \%$. Ferreira (2005) reports a debt level of 36\%, whereas Ferreira and do Nascimento (2005) report an increase from 33\% to 56\% of GDP over the past decade.

In our model residual government expenditures constitute $\Delta_{C^{g}}=2 \%$ of private sector output. We pick this value so that after labor taxes clear the government budget constraint, the total tax revenue will be close to 35\% of GDP and the fraction of labor tax revenue is close to 5.2\%. These are the numbers reported in Immervoll et al. (2006).

We summarize our calibration results in Table 6. Fig. 3 presents the equilibrium profiles for assets, labor supply, consumption, and income for both sectors per agent type.

\section{Policy experiment and results}

In this section we describe our policy reform experiment and report the results. We begin with an economy in its steady state using policy parameters reported in Tables 4 and 5. Parameters are chosen to match the Brazilian economy in 2000

Table 4

Model parameters

\begin{tabular}{|c|c|c|}
\hline Parameters & & Observation/comment/source \\
\hline \multicolumn{3}{|l|}{ Preferences } \\
\hline Discount factor & $\beta=0.998$ & To match $\frac{K}{Y}$ \\
\hline Inverse of intertemporal & $\sigma=2$ & $\begin{array}{l}\text { Issler and Piqueira (2000) and Soriano and Nakane } \\
\text { (2003) }\end{array}$ \\
\hline \multicolumn{3}{|l|}{ Elasticity of substitution } \\
\hline Leisure & $\gamma=0.23$ & To match retirement age \\
\hline \multicolumn{3}{|l|}{ Private production } \\
\hline TFP & $A=1$ & Normalization \\
\hline Productivity of public good $G$ & $\alpha_{1}=0.1$ & Hulten (1996) \\
\hline Capital productivity & $\alpha_{2}=0.4$ & Ferreira and do Nascimento (2005) \\
\hline Human capital productivity & $\alpha_{3}=0.6$ & \\
\hline Capital depreciation & $\delta_{p}=5 \%$ & Feu (2004) and Ferreira and do Nascimento (2005) \\
\hline Long run growth rate & $g=2.65 \%$ & http://www.brazil.org.uk \\
\hline \multicolumn{3}{|l|}{ Public production } \\
\hline TFP for public good production & $Z=0.1$ & Sensitivity analysis \\
\hline \multirow[t]{2}{*}{ Human capital productivity } & $\chi=1$ & Sensitivity analysis \\
\hline & $\eta=0.5$ & Sensitivity analysis \\
\hline $\begin{array}{l}\text { Fraction of civil servant human capital used for } \\
\text { production of public good } G\end{array}$ & $\omega_{h}=0.5$ & Sensitivity analysis \\
\hline Capital depreciation & $\delta_{g}=5 \%$ & Feu (2004) and Ferreira and do Nascimento (2005) \\
\hline \multicolumn{3}{|l|}{ Human capital } \\
\hline Efficiencyprofile & $e_{j}(\theta)$ & Turra and Queiroz (2005a) and Fig. 2 \\
\hline Efficiency loss after retirement & $\varphi=0.65$ & To match early retirement period sensitivity analysis \\
\hline Population growth rate & $n=1.8 \%$ & OECD-Factbook 2006 \\
\hline
\end{tabular}


Table 5

Policy parameters

Source

Labor allocation

Fraction of civil servants

Private sector employees

Expenditures

Public wages as a fraction of private wages

Indexation parameters (generosity of pensions)

Years of past active income for pension base; private

Years of past active income for pension base; public

Investment in public good (in \% of private sector output)

Residual government expenditure (in \% of private sector

output)

Government bonds (in \% of private sector output)

Taxes

Labor tax rate; private

Labor tax rate; public

Capital tax rate

Consumption tax rate

Tax on bequests

Social security tax-private

Social security tax-public
$\begin{array}{ll}N^{g}=7 \% & \text { Social Security Ministry of Brazil (2002) } \\ N^{p}=93 \% & \text { Social Security Ministry of Brazil (2002) }\end{array}$

$\xi=1.01$

$\Psi_{j}^{p}\left(\theta^{p}\right), \Psi_{j}^{g}\left(\theta^{g}\right)$ for

$j=\left\{J_{e}, \ldots, J\right\}$

$J_{p}=5$

$J_{g}=1$

$\Delta_{G}=3 \%$

$\Delta_{\mathrm{Cg}}=2 \%$

$\Delta_{B}=13 \%$

Foguel et al. (2000) and to match public sector wage bill Based on Bonturi (2002) see Fig. 2

Bonturi (2002)

Integrality

Calderon et al. (2003) report 2.5\%

To fix total tax revenue at 35\% of GDP, Immervoll et al. (2006)

To match debt level of $36 \%$ of GDP reported in Ferreira (2005)
To match tax revenue shares in Immervoll et al. (2006)

To match tax revenue shares in Immervoll et al. (2006) and the fact that public workers pay lower labor taxes than private sector workers

Immervoll et al. (2006)

Immervoll et al. (2006)

Immervoll et al. (2006)

Immervoll et al. (2006) and authors' own calculation

Immervoll et al. (2006) and authors' own calculation

Table 6

Model outcomes that match Brazilian data

\begin{tabular}{|c|c|c|c|}
\hline Moments & Model & Data & Source \\
\hline Capital output ratio & $\frac{K}{Y}=2.52$ & 2.6 & Gomes et al. (2003) \\
\hline Interest rate & $R=8.2 \%$ & $9.6 \%$ & Rogoff $(2005)$ \\
\hline \multicolumn{4}{|l|}{ Government size (all in \% of private sector output) } \\
\hline Total tax revenue & $34.9 \%$ & $35 \%$ & Immervoll et al. (2006) and authors' own calculations \\
\hline Labor tax revenue & $4.79 \%$ & $5.2 \%$ & Immervoll et al. (2006) and authors' own calculations \\
\hline Capital tax revenue & $7.28 \%$ & $7.6 \%$ & Immervoll et al. (2006) and authors' own calculations \\
\hline Consumption tax revenue & $15.1 \%$ & $15.5 \%$ & Immervoll et al. (2006) and authors' own calculations \\
\hline Soc. sec. tax revenue & $7.2 \%$ & $6.2 \%$ & Immervoll et al. (2006) and authors' own calculations \\
\hline Bequest tax revenue & $0.51 \%$ & $0.5 \%$ & Immervoll et al. (2006) and authors' own calculations \\
\hline \multicolumn{4}{|l|}{ Demographics } \\
\hline Population > 65 & $14.16 \%$ & $15 \%$ & Carvalho and Wong (2004) \\
\hline $\begin{array}{l}\text { Endogenous fraction of civil servants per cohort with early } \\
\text { retirement }\end{array}$ & $n^{g}=9.9 \%$ & $14 \%$ & Immervoll et al. (2006) \\
\hline \multicolumn{4}{|l|}{ Expenditures (all in \% of private sector output) } \\
\hline Wage bill public sector workers & $6.0 \%$ & $5.1 \%$ & Social Security Ministry of Brazil (2002) and authors' calculation \\
\hline Public pension payments & $5 \%$ & $5 \%$ & Souza et al. (2004) \\
\hline Private pensions payments & $8 \%$ & $6.3 \%$ & Souza et al. (2004) \\
\hline Debt & $35 \%$ & $36 \%$ & Ferreira (2005) \\
\hline \multicolumn{4}{|l|}{ Pension deficit (all in \% of private sector output) } \\
\hline Total pension deficit & $5.8 \%$ & $5.5 \%$ & Souza et al. (2004) \\
\hline Pension deficit from public sector & $4.4 \%$ & $3.5 \%$ & Souza et al. (2004) \\
\hline Pension deficit from private sector & $1.5 \%$ & $1.5 \%$ & Souza et al. (2004) \\
\hline Pension contribution rate, public & $81.8 \%$ & $80 \%$ & Souza et al. (2004) \\
\hline Pension contribution rate, private & $13.15 \%$ & $13.4-36 \%$ & $\begin{array}{l}\text { Ministry of Budget and Administration (1999) and Souza et al. } \\
\text { (2004) }\end{array}$ \\
\hline
\end{tabular}


with an average retirement age for civil servants of 55 . We then mimic the policy reform in 2003 and reduce the generosity of public pension payments by $20 \%$ and enforce an age limit for retirement of $60\left(J_{e}=8\right)$ in both sectors. We introduce this shift in government policy as a permanent and unexpected change in the replacement rate matrix $\Psi^{g}$. We let labor taxes $\tau^{L}$ adjust to clear the government budget constraint in each period and then calculate the new steady state and the transition path from the old to the new steady state. We call this our benchmark experiment and denote it as $E_{0}$. In this policy experiment the current civil servants are grandfathered and thus not directly affected by this policy reform. Of course they will be influenced by general equilibrium effects such as changes in factor prices and by changes in tax rates.

We summarize the steady state results of our experiment in Table 7, where we report percentage changes to the benchmark outcomes for key variables such as output $(Y)$, capital $(K)$, human capital employed in the private sector $\left(H^{p}\right)$,

Table 7

Pension policy reform in the public sector

\begin{tabular}{|c|c|c|c|c|c|c|c|}
\hline & $\% \Delta Y$ & $\% \Delta K$ & $\% \Delta H^{p}$ & $\% \Delta H^{g}$ & $\Delta J_{e}^{p}$ & $\Delta J_{e}^{g}$ & $\% \Delta \tau$ \\
\hline$E_{0}:\left\{\begin{array}{l}\sigma=2 \\
\alpha_{1}=0.1 \\
\tau_{L} \text { adjusts } \\
J_{1}^{g}=55\end{array}\right.$ & 2.85 & 3.65 & 0.06 & 25.6 & {$[0,0,0,0]$} & {$[5,5,5,5]$} & -7.45 \\
\hline
\end{tabular}

Reduction of pension replacement rate by $20 \%$ and enforcing a minimum retirement age of 60 .

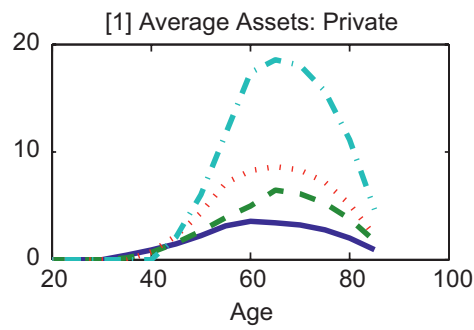

[3] Labor Supply: Private

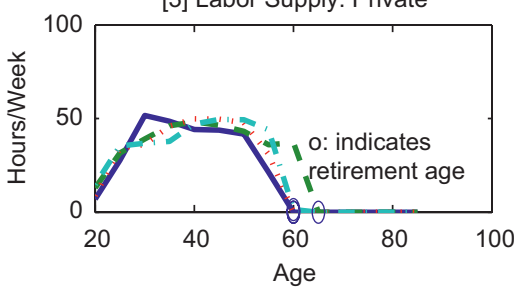

[5] Consumption: Private

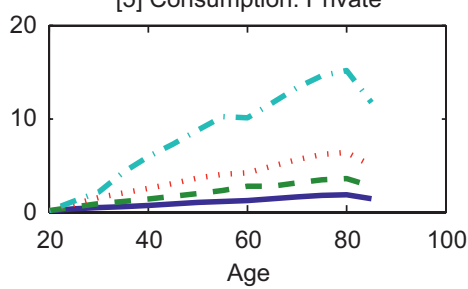

[7] Income Profile: Private

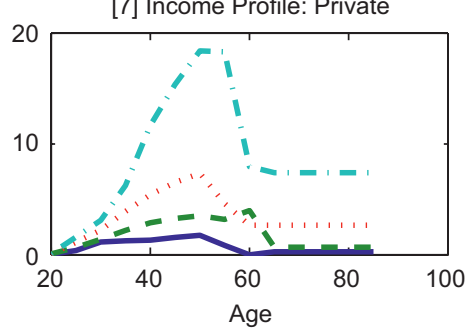

[2] Average Assets: Public

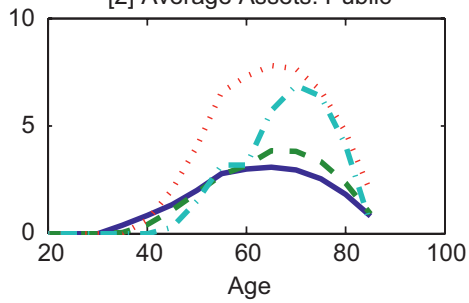

[4] Labor Supply: Public

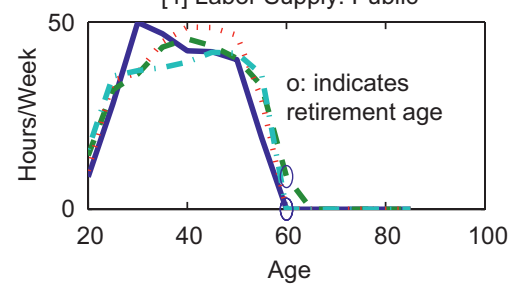

[6] Consumption: Public

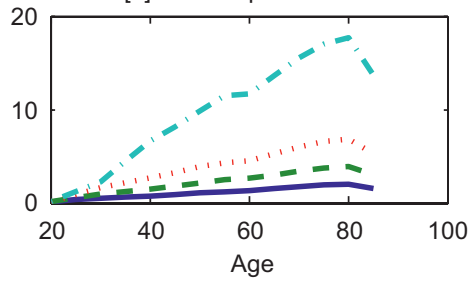

[8] Income Profile: Public

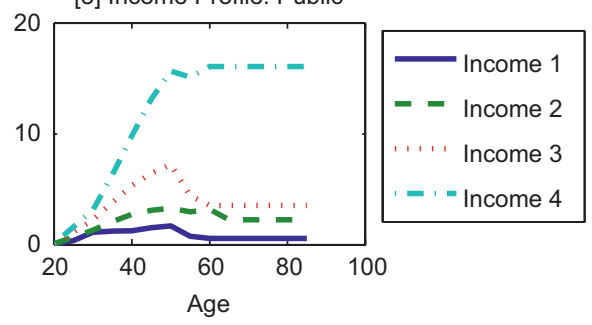

Fig. 4. Steady state after replacement ratios of public sector have been cut. 


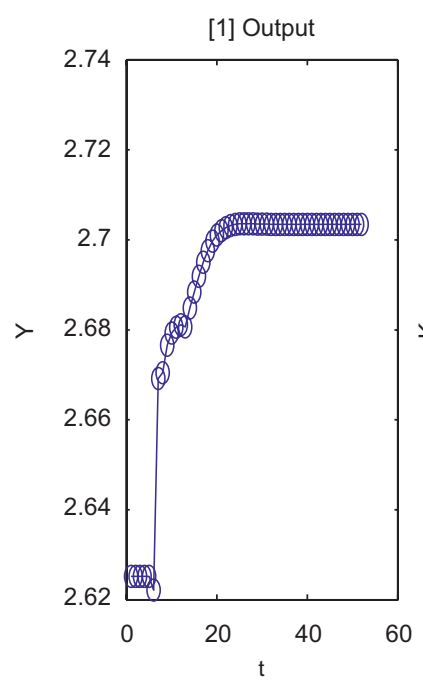

[4] Wages

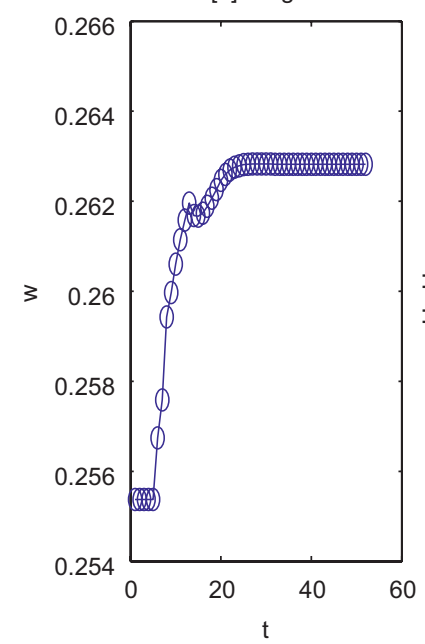

[2] Capital

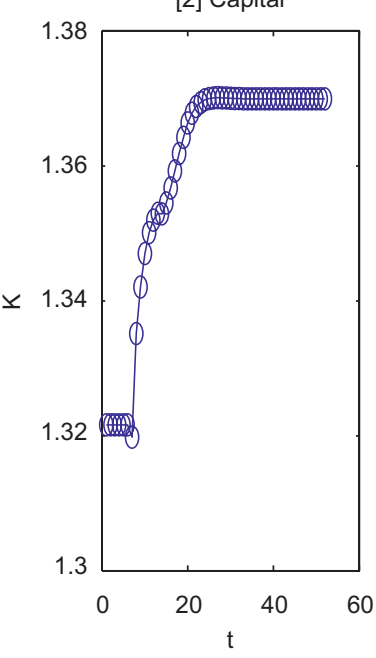

[5] Human Capital

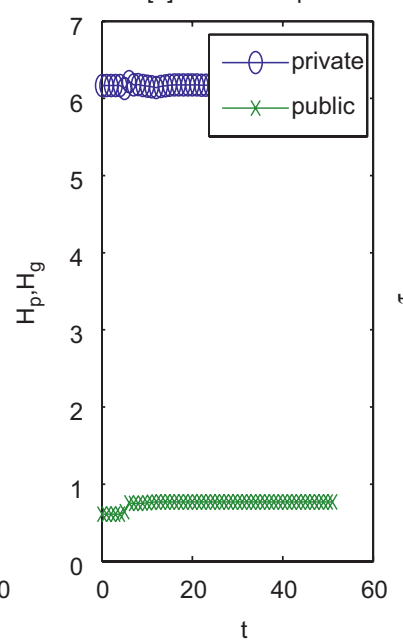

[3] Interest

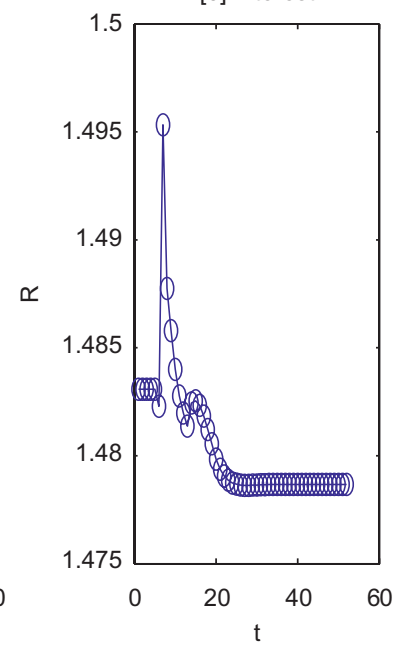

[6] Labor Tax

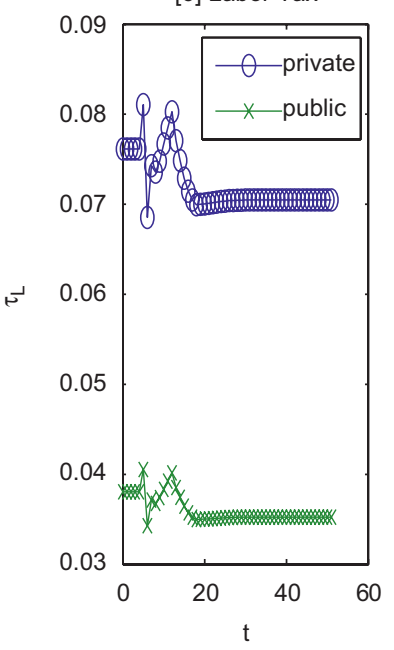

Fig. 5. Transition after decreasing the replacement ratios in the public sector with labor tax adjusting to clear the government budget constraint.

human capital employed in the government sector $\left(H^{g}\right)$, as well as changes in the retirement age per agent type and sector and changes in the adjusting tax rates. The benchmark experiment is labelled $E_{0}$. Fig. 4 presents the age profiles for assets, labor supply, consumption, and income of the new steady state after running the benchmark experiment. Fig. 5 illustrates the transitions.

\subsection{Efficiency gain}

As is evident from the result in the top panel of Table 7 eliminating the generous pension policy leads to a substantial efficiency gain. Particularly, the reform results in an increase of steady state output of $2.85 \%$. There are two main channels, relative increases in physical capital and human capital, that drive this result.

As pension payments become less generous, the rate of capital accumulation increases. This is the direct positive savings effect from decreasing transfers late in life. Together with the positive income effect from the lower labor tax rates and the resulting higher labor supply, savings will increase in both sectors which then results in a larger steady state capital stock. From panel [2] in Figs. 3 and 4 we see that public sector workers start accumulating capital approximately 10 years earlier in the new regime. This is a logical consequence of the lower pensions of public sector workers under the new regime.

After decreasing the generosity of public sector pensions and enforcing a minimum retirement age of 60 years, all public sector worker types delay their retirement by 5 years. Keeping public sector workers in the labor force longer increases public sector human capital $H^{g}$ by $25 \%$. At the same time public sector retirees who were working in the (informal) private sector after retirement, are now missing in the private sector. Since the government has to finance a smaller pension 
program, labor taxes go down from originally $7.6 \%$ to $7 \%$. This increases the effective wage and labor supply increases in all sectors. The increase in labor supply more than offsets the missing public sector retirees that were previously working in the informal private sector, so that overall, human capital in the private sector $H^{p}$ increases slightly.

Comparing our results to Herbertsson and Orszag (2003) we find that the cost of early retirement is lower in Brazil than in OECD countries on average. The countries that push up the average cost in their OECD sample are small European countries with very generous pensions systems, very high participation rates, low population growth rates, and hence a rather old average population (e.g. Austria, Hungary, Belgium, or France). In those countries the cost of early retirement was estimated to be around $13 \%$ of GDP in 2000. The one country in their sample that probably resembles Brazil the most is Mexico where the cost of early retirement is much lower at $1.6 \%$ of GDP for the year 2000 . This figure is much closer to our result for Brazil.

The most important difference between our paper and Herbertsson and Orszag (2003) is that our pension reform concentrates on relatively small group of public sector workers, whereas Herbertsson and Orszag (2003) look at the reform of the entire pension programs. Since our simulated pension reform only affects the relatively small group of public sector workers directly with respect to the generosity of their pensions and their minimum retirement age, one might expect the effects of the reform to be much smaller than in Herbertsson and Orszag (2003) where early retirement affects a larger percentage of the labor force due to the higher participation rates. In addition, since in Brazil some public retirees work in the private sector the loss of human capital due to early retirement is mitigated. However, we find the effect of public sector pension reform to be large.

From Fig. 5 we conclude that transitions are monotone in output and physical capital. The income and savings effects are clear cut and lead to a steady increase in physical capital. Interest rates are non-monotonic which has to do with the grandfathering effects we describe below.

\subsection{Welfare gain}

Our welfare analysis is presented in Fig. 6. The top panel shows the compensating consumption in percent of per period percentage adjustment to consumption for private sector workers over the transition path. That is for every agent type $\theta$ over transition time $t$ we calculate what fixed percentage of consumption has to be added/subtracted in each period to make the agent indifferent between the steady state of the original (more generous) public pension policy and the new
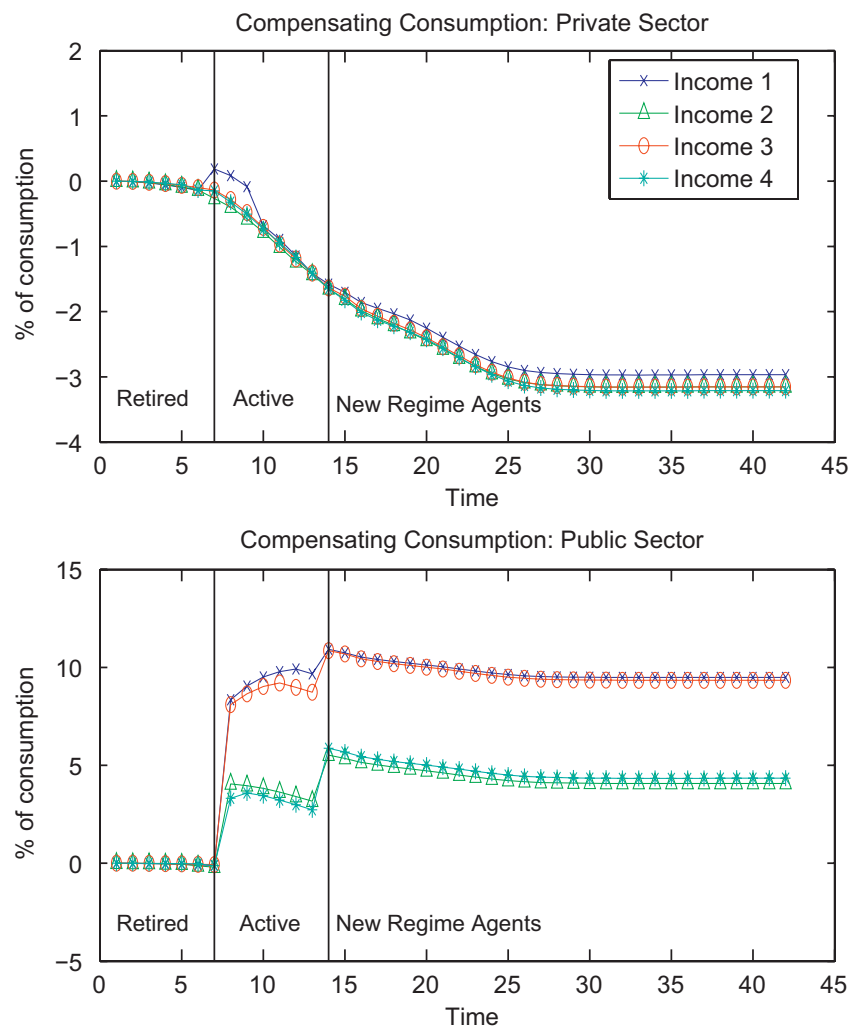

Fig. 6. Compensating consumption given to individuals to offset the policy change that induces civil servants to postpone their retirement from age 55 to 60. The adjustment is made as equal percentage change in consumption in every period. 
steady state under the less generous public pension policy. More formally this is expressed as

$$
\begin{aligned}
\pi_{1} u\left(c_{1 J}(\theta), l_{1 J}(\theta)\right)+\beta \pi_{2} u\left(c_{1 J}(\theta), l_{1 J}(\theta)\right)+\cdots+\beta^{J-1} \pi_{J} u\left(c_{1 J}(\theta), l_{1 J}(\theta)\right) \\
=\pi_{1} u\left(\left(1+\Delta_{t}(\theta)\right) c_{t 2}(\theta), l_{t J}(\theta)\right)+\beta \pi_{2} u\left(\left(1+\Delta_{t}(\theta)\right) c_{t J}(\theta), l_{t J}(\theta)\right) \\
\quad+\cdots+\beta^{J-1} \pi_{J} u\left(\left(1+\Delta_{t}(\theta)\right) c_{t J}(\theta), l_{t J}(\theta)\right),
\end{aligned}
$$

where we compare the utility of life time consumption and leisure paths of an agent type $\theta$ at transition time $t$ to utility of life time income in the old steady state. We then adjust the consumption stream of the transition path until the life time utility in the new regime is equal to life time utility in the old regime. If an agent's compensation turns out to be positive, then the agent loses from the reform as she has to be compensated in order to make her as well off as before. If an agent's compensation is negative, the agent is a winner from the reform.

The black vertical line distinguishes generations that were born in the old steady state and are grandfathered into the new regime. These agents still benefit from the generous public pensions, but have to adjust to the new prices of capital and labor over their remaining life time. The bottom panel shows the welfare analysis for public sector workers.

The effects from grandfathering are straightforward. Agents who are already retired (the first 8 transition generations in the private sector and the first 7 transition generations in the public sector) are barely affected by the reform. The only effect on them is via factor prices and since they are already retired, changes in the wage rate will not affect their income levels anymore. So only changes in the interest rate affect their savings income and their savings decision until they die. As a consequence, the effects remain small in terms of welfare. Agents who are still active when the reform is started tend to be affected by changes in wages as well. Since agents can adjust their labor supply to changes in wages, we see that workers in the public sector tend to lose more from the reform when they are still working, despite the fact that nothing in their replacement rates changes due to grandfathering.

Agents who are born in the new regime are affected the most by the pension reform. We see that private sector workers are the winners of the reform as the compensation that would make them indifferent between the old steady state and the new regime is negative (compare top panel of Fig. 6). The biggest winners of the reform are the high income private sector workers, denoted income 4 but differences in welfare effects across income types are small.

The opposite holds true for public sector workers (compare bottom panel of Fig. 6). We see that we need to compensate them with up to $10 \%$ of their consumption in order to make them indifferent between the two regimes. The lowest income group (denoted income 1) in the public sector loses the most in terms of percentage of their consumption (10\% of their per period consumption on average). So the reform directly benefits rich individuals in the private sector and hurts poor individuals in the public sector.

\section{Sensitivity analysis and alternative policy experiments}

We present the results of the sensitivity analysis in Table 8. We concentrate the sensitivity analysis on parameters with weak empirical support and on parameters that have been shown to have strong effects on outcomes in this type of model like preference parameters in experiments $E_{1 a}$ and $E_{1 b}$ and production parameters for the public good in experiments $\mathrm{E}_{3}-\mathrm{E}_{5}$. Where necessary, we recalibrate the model to match the Brazilian economy.

We next investigate alternative policy experiments and report the results in Table 9. First we implement alternative fiscal policies in experiments $E_{6}$ and $E_{7}$ as well as a variant of a small open economy where we fix the interest rate in experiment $E_{8}$. We then investigate the effects of lowering the generosity of public pensions without enforcing a minimum retirement age at the same time in experiments $E_{9 a}$ to $E_{9 d}$. In experiment $E_{10}$ we enforce a minimum retirement age of 60 without reducing the generosity of public pensions. In experiment $\mathrm{E}_{11}$ we again reduce the generosity of public pension by $20 \%$ and enforce a minimum retirement age of 65 in both sectors. Finally, in experiment $\mathrm{E}_{12}$ we assume that retirees are not working in the private

\begin{tabular}{|c|c|c|c|c|c|c|c|}
\hline & $\% \Delta Y$ & $\% \Delta K$ & $\% \Delta H^{p}$ & $\% \Delta H^{g}$ & $\Delta J_{e}^{p}$ & $\Delta J_{e}^{g}$ & $\% \Delta \tau$ \\
\hline $\mathrm{E}_{1 \mathrm{a}}: \sigma=3$ & 2.80 & 3.40 & -0.02 & 25.25 & {$[0,0,0,0]$} & {$[5,5,5,5]$} & -7.85 \\
\hline $\mathrm{E}_{1 \mathrm{~b}}: \sigma=1.2$ & 3.09 & 3.76 & 0.19 & 25.45 & {$[0,0,0,0]$} & {$[5,5,5,5]$} & -10.90 \\
\hline$E_{2 a}: \alpha_{1}=0$ & 0.44 & 1.06 & 0.03 & 25.47 & {$[0,0,0,0]$} & {$[5,5,5,5]$} & -5.93 \\
\hline $\mathrm{E}_{2 \mathrm{~b}}: \alpha_{1}=0.05$ & 1.64 & 2.32 & 0.06 & 25.53 & {$[0,0,0,0]$} & {$[5,5,5,5]$} & -6.13 \\
\hline $\mathrm{E}_{2 \mathrm{c}}: \alpha_{1}=0.15$ & 4.59 & 5.29 & 0.095 & 25.65 & {$[0,0,0,0]$} & {$[5,5,5,5]$} & -7.16 \\
\hline $\mathrm{E}_{3 \mathrm{a}}: \eta=0.25$ & 2.76 & 3.44 & 0.0638 & 25.64 & {$[0,0,0,0]$} & {$[5,5,5,5]$} & -7.455 \\
\hline $\mathrm{E}_{3 \mathrm{~b}}: \eta=0.75$ & 3.18 & 3.86 & 0.0646 & 25.638 & {$[0,0,0,0]$} & {$[5,5,5,5]$} & -7.455 \\
\hline $\mathrm{E}_{4 \mathrm{a}}: \chi=0.5$ & 2.39 & 3.06 & 0.0636 & 25.639 & {$[0,0,0,0]$} & {$[5,5,5,5]$} & -7.451 \\
\hline $\mathrm{E}_{4 \mathrm{~b}}: \chi=1.5$ & 3.28 & 3.96 & 0.0635 & 25.639 & {$[0,0,0,0]$} & {$[5,5,5,5]$} & -7.453 \\
\hline $\mathrm{E}_{5}: \omega_{h}=0.3$ & 2.77 & 3.45 & 0.06 & 25.54 & {$[0,0,0,0]$} & {$[5,5,5,5]$} & -7.45 \\
\hline
\end{tabular}

Table 8

Sensitivity analysis 
Table 9

Alternative policy experiments

\begin{tabular}{|c|c|c|c|c|c|c|c|}
\hline & $\% \Delta Y$ & $\% \Delta K$ & $\% \Delta H^{p}$ & $\% \Delta H^{g}$ & $\Delta J_{e}^{p}$ & $\Delta J_{e}^{g}$ & $\% \Delta \tau$ \\
\hline $\mathrm{E}_{6}: \tau_{K}$ adjusts & 8.24 & 14.44 & -0.13 & 46.80 & {$[0,0,0,0]$} & {$[5,10,5,5]$} & -31.34 \\
\hline $\mathrm{E}_{7}: \tau_{\mathrm{C}}$ adjusts & 6.30 & 9.07 & 0.17 & 46.94 & {$[0,0,0,0]$} & {$[5,10,5,5]$} & -10.87 \\
\hline $\mathrm{E}_{8}: R_{t}=R_{1}$ & 21.15 & 51.38 & -0.57 & 44.22 & {$[0,0,0,0]$} & {$[5,10,5,5]$} & -75.15 \\
\hline$E_{9 a}:-20 \%$ pension & 1.3 & 2.05 & 0.33 & 4.41 & {$[0,0,0,0]$} & {$[0,0,0,0]$} & -10.94 \\
\hline$E_{9 b}:-30 \%$ pension & 2.1 & 3.3 & 0.51 & 6.88 & {$[0,0,0,0]$} & {$[0,0,0,0]$} & -17.07 \\
\hline $\mathrm{E}_{9 \mathrm{c}}:-50 \%$ pension & 3.85 & 6.13 & 0.92 & 12.64 & {$[0,0,0,0]$} & {$[0,0,0,0]$} & -30.60 \\
\hline$E_{9 d}:-80 \%$ pension & 7.75 & 11.58 & 0.82 & 46.88 & {$[5,0,0,0]$} & {$[0,10,5,5]$} & -36.56 \\
\hline $\mathrm{E}_{10}$ : enforce retirement age $J_{1}^{g}=60$ only & 3.15 & 3.85 & 0.23 & 25.21 & {$[0,0,0,0]$} & {$[5,5,5,5]$} & -8.67 \\
\hline$E_{11}:-20 \%$ pension and enforced retirement age $J_{1}^{g}=65$ & 9.51 & 11.12 & 3.81 & 46.26 & {$[5,0,5,5]$} & {$[10,10,10,10]$} & -54.6 \\
\hline$E_{12}$ : retirees not working in private sector, $\varphi=0.5$ & 3.14 & 3.85 & 0.23 & 25.21 & {$[0,0,0,0]$} & {$[5,5,5,5]$} & -8.67 \\
\hline
\end{tabular}

sector after they retire by imposing a very high efficiency loss on retired workers' productivity $(\varphi=0.5)$. This effectively makes them unwilling to work after retirement. We next briefly summarize the results of these alternative experiments.

Experiments $\mathrm{E}_{1 \mathrm{a}}, \mathrm{E}_{1 \mathrm{~b}}$ : Changing the preference parameter $\sigma$ requires a recalibration of the model, since the rate of capital accumulation is strongly influenced by the intertemporal elasticity of substitution. If the smoothing motive becomes weaker (less curvature on the utility function) at $\sigma=1.2$ agents are more responsive to the policy reform so that the policy effects on long run income levels are larger than when the smoothing motive is strong $(\sigma=3)$. However, the differences in the effects on the aggregate steady state income are small.

Experiments $E_{2 a}-E_{2 c}$ : Changing the productivity of the public good in the final goods production function can have substantial effects. The intuition is clear. Civil servants' human capital is an input into producing the public good. If we cut pensions for civil servants and keep them in the labor force longer, then more human capital is retained and hence more of the public good can be produced. If, in the next step, the public good is very productive, i.e. $\alpha_{1}=0.15$, then the effect on steady state output is large (4.59\%). If, on the other hand, the public good is not productive at all, $\alpha_{1}=0$, then the effect on final goods output are triggered purely by household savings and labor supply which result in more modest changes in output $(0.44 \%$ ). The relationship between the infrastructure productivity parameter and the steady state output effect of pension reform is monotonic as can be seen from experiment $E_{2 b}$.

Experiment $E_{3}-E_{5}$ : Our results are robust to changing parameters in the public capital production function. Changes have the expected effect, that is, as we decrease $\eta, \chi$, and $\omega_{h}$ the influence of civil servants' human capital in producing the public good is reduced, and the output effects of the reform are smaller. The magnitude of these changes is very small.

Experiment $\mathrm{E}_{6}$ : In this experiment we let the capital tax adjust to clear the government budget constraint in reaction to the pension reform. Capital taxes have large effects on capital accumulation. So if capital taxes can be reduced due to the reform, physical capital accumulation accelerates. In addition, there is more human capital available in the public sector as civil servants postpone their retirement even further than in the benchmark experiment. Capital taxes tend to distort the model economy more strongly than labor taxes, so that any government policy that results in a reduction of capital taxes will have stronger effects.

Experiment $\mathrm{E}_{7}$ : We ran the same set of experiments with the consumption tax adjusting to clear the government budget constraint and find that the effects are larger than in the benchmark experiment.

Experiment $\mathrm{E}_{8}$ : The Brazilian interest rate is very high, around $9.6 \%$ in 2005. It is often reported that the Brazilian interest rate is determined by the Brazilian government debt and in that sense 'relatively' independent of the market 'world interest' rate (see Rogoff, 2005 who gives some explanations about why the real interest rate in Brazil is so high). We see this as justification for the assumption of a closed economy in the benchmark experiment. However, we did run an open economy version of our model, where we fix the interest rate at $8.2 \%$ (our initial calibration for Brazil). We found that our results are magnified by this policy. In a full general equilibrium model prices adjust in reaction to household decisions, so that as households accumulate more capital, the interest rate decreases. However, if the interest rate is fixed, households increase their savings even further. This results in high levels of physical capital in the new steady state, which increases the output effect to $21.15 \%$ of GDP compared to $2.85 \%$ in the full general equilibrium version of our model.

Experiment $\mathrm{E}_{9 \mathrm{a}}-\mathrm{E}_{9 \mathrm{~d}}$ : In these experiments we reduce the generosity of pension payments without enforcing a minimum retirement age of 60 . We see that reducing pension payments to civil servants by $20-30 \%$ is not enough to induce later retirement. Consequently the effects of such a reform will be smaller than the benchmark. Reducing the generosity by $50 \%$ has larger effects that come largely via lower labor taxes and the public households' higher savings rate in reaction to the drop in retirement income. We require a reduction of more than $50 \%$ to actually induce late retirement.

Experiment $\mathrm{E}_{10}$ : In this experiment we assume that the government postpones the time of retirement of public sector workers by 5 years without cutting the generosity of pension payments simultaneously. We find that these results are very 
close to the results in the benchmark experiment. This suggests that the reduction of the generosity of pension payments by $20 \%$ does not play a large role in affecting the overall results (compare also results from $\mathrm{E}_{13}$ ) and large parts of this reform are driven by the postponed retirement and not necessarily by the reduction of payments. Only sizeable reductions in generosity of pension payments that actually lead to postponed retirement will have large effects as was shown in experiments $\mathrm{E}_{9 \mathrm{c}}$ and $\mathrm{E}_{9 \mathrm{~d}}$.

Experiment $\mathrm{E}_{11}$ : This experiment is closest to what has been investigated in the pension reform literature, namely the reform of the entire pension system including both private and public sector workers. We see that if we reduce the generosity of public sector pensions by $20 \%$ and enforce a minimum retirement age of 65 for both sectors, some private sector workers will retire later than in the benchmark regime. This augments the effects of the policy reform since now a larger amount of human capital is retained longer in the labor market. Private sector human capital increases by more than $3 \%$. This results in an increase of output by almost $10 \%$.

Experiment $\mathrm{E}_{12}$ : Our results are robust to the assumption that retirees are allowed to work in the private sector after they retire.

In general, our results are quantitatively stable and are centered around $3 \%$ of private sector output if civil servant retirement is postponed until age 60 . If public capital becomes more productive in the final goods production process, then the extra output from decreasing the generosity of public pensions is closer to $5 \%$ of GDP. Alternative fiscal policies (e.g. adjusting the consumption tax or the capital tax instead of the labor tax rate) more than double the magnitude of the effects from our benchmark experiment. We get the largest effects in an open economy version where interest rates are fixed to the initial steady state interest rate. This result is likely to overstate the impact of the pension reform, since the prevalent interest rate in Brazil has been shown to depend largely on the inner workings of the Brazilian economy. ${ }^{19}$

\section{Conclusion}

In this paper we have studied the adverse effects of extremely generous early retirement provisions for civil servants. We explored the effects of a pension reform for public sector workers on human capital available to public sector production, capital accumulation, the long run level of aggregate income, and on welfare. For this purpose we have used an OLG economy which was calibrated to data from Brazil in year 2000. We have conducted policy reforms that induced civil servants to postpone the age at which they retire. These policy reforms consist of decreasing replacement rates which do allow for sizable cuts in taxation and the enforcement of a minimum retirement age of 60 . We found that these retirement policies ensure that civil servants postpone retirement by 5 years from age 55 to age 60 which raises aggregate steady state income by over $3 \%$. The transition to the new steady states lasts about 100 years. The welfare gains to private sector employees of such policy reforms are large and exceed 3\% of consumption. These welfare gains are relatively evenly distributed across the income distribution. Of course, civil servants stand to lose from such a reform. The computed welfare losses for some civil servants are as high as $10 \%$ of consumption.

For the purpose of this analysis we have abstracted from the potentially important issue of population ageing. We have also abstracted from alternative uses of public funds released by these policy experiments such as higher public education expenditure or higher investment in infrastructure. We leave these issues for future research.

\section{Acknowledgements}

We would like to thank participants at the Midwest Macroeconomics Meetings at Washington University in St. Louis, the EEA-ESEM 06 Conference in Vienna, the 62nd Congress of the International Institute of Public Finance in PaphosCyprus, the PET 06 Conference in Hanoi, Stephen Parente, and two anonymous referees for helpful comments.

\section{Appendix A}

\section{Algorithm.}

(1) Guess an initial capital level $K$ and an initial labor supply schedule $L$

(2) Solve for $Y, G, B, w^{p}, w^{g}, R$ and $q$

(3) Household

(a) Solve household backwards for $s(\theta), c(\theta), l(\theta)$, and $J_{1}(\theta)$

(b) Check if $l(\theta)>1$, if yes, set $l(\theta)=1$ and solve backwards again for the corner solution case

(4) Aggregate steady state assets $A$

(5) Bequests

(6) Subtract bonds from asset holdings to get the new capital stock for production: $K^{\prime}=A-B$

(7) Update $K^{\text {new }}=\lambda K^{\prime}+(1-\lambda) K$

(8) Use the government budget constraint to solve for labor tax $\tau_{L}$

(9) Repeat from step 2 until $K, \tau^{L}$, and $J_{1}(\theta) \forall \theta$ converge

\footnotetext{
${ }^{19}$ See Rogoff (2005) for an explanation of the unusually high real interest rate in Brazil.
} 
The algorithm for transitions works very similar. After calculating the old and the new steady state, we guess a capital vector $K_{v}$ and an initial labor supply schedule vector $L_{v}$ of dimension $(1 \times$ Transition Time), where transition time is an exogenously fixed time horizon that has to be picked large enough so that transition to the new steady state level can occur. From our transition graph in Fig. 5 we see that although Transition Time $=42$, the actual transition to the steady state takes about 20 periods which is roughly 100 years.

\section{References}

Ahituv, A., Zeira, J., 2000. Technical progress and early retirement. C.E.P.R. Discussion Papers 2614.

Ai, C., Cassou, S.P., 1995. A normative analysis of public capital. Applied Economics 27, 1201-1209.

Auerbach, J.A., Kotlikoff, L.J., 1987. Dynamic Fiscal Policy. Cambridge University Press, Cambridge, MA.

Barro, R.J., 1990. Government spending in a simple model of endogenous growth. Journal of Political Economy 98 (5), S103-S125.

Blöndal, S., Scarpetta, S., 1998. Falling participation rates among older workers in the OECD countries. OECD, Paris.

Blundell, R., Meghir, C., Smith, S., 2002. Pension incentives and the pattern of early retirement. Economic Journal 112, C153-C170.

Bonturi, M., 2002. The Brazilian pension system: recent reforms and challenges ahead. OECD Economics Department Working Paper No. 340.

Bresser-Pereira, C.L., 1990. The perverse macroeconomics of debt. In: Fukuchi, T., Kagami, M. (Eds.), Perspectives on the Pacific Basin Economy: A Comparison of Asia and Latin America. Institute of Developing Economies, Toquio.

Calderon, C., Serven, L., 2003. The output cost of Latin America's infrastructure gap. The Limits of Stabilization: Infrastructure, Public Deficits, and Growth in Latin America. Stanford University Press and the World Bank.

Calderon, C., Easterly, W., Serven, L., 2003. Latin America's infrastructure in the era of macroeconomic crises. In: Easterly, W., Serven, L. (Eds.), The Limits of Stabilization Infrastructure, Public Deficits and Growth in Latin America. World Bank, Washington, DC.

Carvalho, J.A.M., Wong, L.R., 2004. Age structural transition in Brazil-demographic bonuses and emerging challenges. Center of Development and Regional Planning (CEDEPLAR), UFMG/Brazil.

Colucci, D., 2003. Steady states in the OLG model with seignorage and long-lived agents. Research in Economics 57, $371-381$.

Conde-Ruiz, J.I., Galasso, V., Profeta, P., 2005. The evolution of retirement. C.E.P.R. Discussion Papers 4863.

Cremer, H., Pestieau, P., 2003. The double dividend of postponing retirement. International Tax and Public Finance 10, $419-434$.

Fehr, H., Sterkeby, W.I., Thogersen, O., 2003. Social security reforms and early retirement. Journal of Population Economics 16, 345-361.

Ferreira, S.G., 2004. Social security reforms under an open economy: the Brazilian case. Revista Brasileira de Economia 58, 343-380.

Ferreira, S.G., 2005. Pension reform in Brazil: transitional issues in a model with endogenous labor supply. IBMEC Economics Discussion Paper 2005-02.

Ferreira, P.C., do Nascimento, L.G., 2005. Welfare and growth effects of alternative fiscal rules for infrastructure investment in Brazil. Manuscript, EPGE-FGV (604)

Ferreira, F.H., Lanjouw, P., Neri, M., 2003. A robust poverty profile for Brazil using multiple data sources. Revista Brasileira De Economia 57 (1), $59-92$.

Feu, A., 2004. Evaluation of capital productivity in Brazil in the XX century. Economy and Energy, April-May, ISSN 1518-2932(43). URL: 〈http://ecen.com/ eee43/eee43e/cap_prd_XX_e.htm).

Foguel, M.N., Gill, I., Mendonca, R., PaesdeBarros, R., 2000. The public-private wage gap in Brazil. Discussion Paper No. 754, Instituto de Pesquisa Econômica Aplicada (IPEA).

Fuster, L., Imrohoroglu, A., Imrohoroglu, S., 2005. Personal security accounts and mandatory annuitization in a dynastic framework. In: Fenge, R., de Menil, G., Pestieau, P. (Eds.), Strategies for Pension Reform. MIT Press, forthcoming (under review).

Giambiagi, F., de Mello, L., 2006. Social security reform in Brazil: achievements and remaining challenges. Economics Department Working Paper No. 534, OECD.

Glomm, G., Jung, J., Lee, C., Tran, C., 2006. Public pensions and capital accumulation: the case of Brazil. CAEPR Working Papers 2006-008.

Gollin, D., 2002. Getting income shares right. Journal of Political Economy 110 (2), 458-474.

Gomes, V., Pessoa, S., Veloso, F., 2003. Evolucao da Produtividade Total de Fatores na Economia Brasileira: Uma Analise Comparativa. Pesquisa e Planejamento Economico 33 (3), 389-434.

Gregory, R., Borland, J., 1999. Recent development in public sector labor markets. Handbook of Labor Economics, vol. 3. North-Holland, Amsterdam, pp. 3573-3630.

Gruber, J., Wise, D., 1998. Social security and retirement: an international comparison. American Economic Review 88 (2), $158-163$.

Gruber, J., Wise, D., 1999. Social Security and Retirement Around the World. University of Chicago Press.

Herbertsson, T.T., 2001. Shrinking labour forces and early retirement. CESifo Forum 2, 31-37.

Herbertsson, T.T., Orszag, M.J., 2003. The early retirement burden: assessing the costs of the continued prevalence of early retirement in OECD countries. IZA Discussion Papers from Institute for the Study of Labor (IZA) 816.

Holtz-Eakin, D., 1994. Public sector capital and the productivity puzzle. Review of Economics and Statistics 76 (1), $12-21$.

Huggett, M., 1996. Wealth distribution in life-cycle economies. Journal of Monetary Economics 38, 469-494.

Hulten, C.B., 1996. Infrastructure capital and economic growth: how well you use it may be more important than how much you have. NBER Working Paper No. 5847.

Hulten, C.B., Schwab, R.M., 1991. Public capital formation and the growth of regional manufacturing industries. In: National Tax Journal, Proceedings of a Conference on the Tax-Exempt Bond Market, pp. 121-134.

Immervoll, H., Levy, H., Nogueira, J.R., ODonoghue, C., Siqueira, R.B., 2006. The impact of Brazil's tax-benefit system on inequality and poverty. IZA Discussion Paper No. 2114.

Issler, J.V., Piqueira, N.S., 2000. Estimating relative risk aversion, the discount rate, and the intertemporal elasticity of substitution in consumption for Brazil using three types of utility functions. Brazilian Review of Econometrics 20, 201-239.

Jimenez-Martin, S., Sanchez, A.R., 2003. An evaluation of the life-cycle effects of minimum pensions on retirement behavior. Journal of Applied Econometrics 22 (5), 923-950.

Kopecky, K., 2005. The trend is retirement. Economie D’avant Garde, Research Report No. 12.

Kotlikoff, L.J., Smetters, K., Walliser, J., 2007. Mitigating America's demographic dilemma by pr-funding social security. Journal of Monetary Economics 54 (2), 247-266.

Laitner, J., 1984. Transition time paths for overlapping-generations models. Journal of Economic Dynamics and Control 7 (2), $111-129$.

Lynde, C., Richmond, J., 1993. Public capital and total factor productivity. International Economic Review 34, 401-414.

Michel, P., Pestieau, P., 1999. Social security and early retirement in an overlapping-generations growth model. Catholique de Louvain-Center for Operations Research and Economics, 17.

Panizza, U., 2000. The public sector premium and the gender gap in Latin America: evidence for the 1980s and 1990s. Working Paper 431, Inter-American Development Bank.

Panizza, U., 2001. Public sector wages and bureaucratic quality: evidence from Latin America. Economia Fall, 97-151.

Panizza, U., Qiang, C.Z.-W., 2005. Public private wage differential and gender gap in Latin America: spoiled bureaucrats and exploited women? The Journal of Socio-Economics 34, 810-833.

Pinheiro, V.C., 2004. The political economy of pension reform in Brazil OECD. URL: 〈http://www.bid.org.uy/sds/doc/IFM-Presentation-CarvalhoPinheiro-2004-E.ppt $\rangle$. 
Rogoff, K., 2005. Strategies for bringing down long-term real interest rates in Brazil. Presentation at Central Bank of Brazil, August 30. URL: 〈www.bcb.gov.br/Pec/SemMetInf2005/Port/Rogoff.pdf).

Rust, J., Phelan, C., 1997. How social security and medicare affect retirement behavior in a world of incomplete markets. Econometrica 65 (4), $781-832$. Soriano, L., Nakane, M.I., 2003. Real balance in the utility function: evidence from Brazil. Working Paper Series 68, Banco Central do Brasil.

Souza, A.P., Zylberstajn, H., Afonso, L.E., Flori, P.M., 2004. Fiscal impacts of social security reform in Brazil. Working Paper.

Souza-Sobrinho, N.F., 2004. Structural reforms and economic performance: Brazil in the 1990s. UCLA.

Turnovsky, S.J., 1999. Productive government expenditure in a stochastically growing economy. Macroeconomic Dynamics 3, 544-570.

Turra, C.M., Queiroz, B.L., 2005a. Before it's too late: demographic transition, labor supply, and social security problems in Brazil. United Nations Expert Group Meeting on Social and Economic Implications of Changing Population Age Structures.

Turra, C.M., Queiroz, B.L., 2005b. Intergenerational Transfers and Socioeconomic Inequality in Brazil: A First Look. Office of Population Research, Princeton University, Princeton, NJ Department of Demography, University of California at Berkeley, Berkeley, CA.

Visco, I., 2000. Welfare systems, ageing and work: an OECD perspective. Banca Nazionale del Lavoro Quarterly Review 53, 3-29.

Werneck, R.L., 2006. An evaluation of the 2003 tax reform effort in Brazil. Brazilian Journal of Political Economy 26 (1(101)), 75-94.

Wise, D.A., 2005. Facing the age wave and economic policy: fixing public pension systems with health care in the wings. Fiscal Studies 26, 5-34.

WorldBank, 2006. World development indicators database, April 〈http://www.worldbank.org/data/dataquery.html〉. 